\title{
The Pleasures of Virtue and the Virtues of Pleasure: The Classicizing Garden in Eleventh- and Twelfth-Century China and Byzantium
}

\section{Curie Virág and Foteini Spingou*}

During the eleventh and twelfth centuries in Byzantium and China, the garden as a site of pleasure was an important literary theme among literati. Although pleasure had long been associated with gardens prior to this period, its simultaneous resurgence in both cultures was specifically linked to new ways of engaging with the classical tradition. This paper explores the nature and significance of the discourse of pleasure in the imagination of gardens in these two culturally distinct, but historically resonant, imperial societies. Noting important parallels and divergences in the literature surrounding pleasurable gardens in the two traditions, it argues that the garden as a site of pleasure was more than a document of the carefree pleasures of communing with nature. Instead, it was a declaration among literati - constrained by their place in a vast imperial bureaucratic system - of their agency, their integrity and, above all, their virtue. Far from being just a psychological or affective state, the pleasures they documented were a testimony of their freedom and moral authority in the face of a vast political order upon which they depended, but that also required their participation and validation as the bearers of the authoritative classical tradition that sustained the very imperial project. As a site charged with references and allusions to the ancient past and its authoritative voices, the garden provided an optimal arena in which those literati retreating from the front lines of official duty could fashion the conditions of their own pleasure, and thereby display their virtue, assert their autonomy and bring to fulfillment their human potentiality.

Keywords: gardens; pleasure; Antiquity; classicizing learning; literati; Song Dynasty; Byzantium; virtue; self-cultivation

During the eleventh and twelfth centuries, the garden became an object of widespread interest among educated elites in both Byzantium and China. Whether they engaged in actual garden-building (as was the case in China) or constructed gardens of the imagination, literati produced elaborate accounts that emphasized pleasure as the defining mode of experiencing

* Correspondence details: Curie Virág (corresponding author), School of History, Classics and Archaeology, University of Edinburgh, 24 Buccleuch Place EH8 9LN, Edinburgh, UK; e-mail: curie.virag@ed.ac.uk; Foteini Spingou, School of History, Classics and Archaeology, University of Edinburgh, 24 Buccleuch Place EH8 9LN, Edinburgh, UK; e-mail: fspingou@ed.ac.uk. 
gardens. Although pleasure-taking had long been associated with gardens in the cultural traditions of both societies, the fact that it became a focus of literary concern during this period is highly significant. Why was pleasure in the garden such a major preoccupation in writings about gardens among Chinese and Byzantine literati during this period? How was pleasure conceived in these texts, and what was the importance of framing such pleasures in the specific context of gardens? What was the connection between this discourse of pleasure and the interest in classicizing forms of learning, which was a pronounced feature of Chinese and Byzantine cultures during this period?

This paper explores the nature and significance of the discourse of pleasure in the imagination of gardens in these two culturally distinct, but historically resonant, imperial societies. Noting striking parallels and divergences between the two traditions, it argues that the pleasures associated with the garden were not just about the carefree delights of communing with nature, but were part of an ethically and political charged discourse in which literati, often constrained by their place in a vast imperial bureaucratic system, asserted their agency, their integrity and, above all, their virtue. Filled with references and allusions to the ancient past and its authoritative voices, the garden provided an optimal arena in which those literati retreating from the front lines of official duty could fashion the conditions of their own pleasure, and thereby display their virtue, assert their autonomy and bring to fulfillment their human potentiality.

Though located at the far ends of Eurasia, and characterized by very distinct cultural and imaginative traditions that seem to have had little direct contact with one another, Byzantium and China bear comparison because they shared some remarkable structural commonalities and underwent comparable large-scale developments. ${ }^{1}$ In both Byzantium and China during the eleventh and twelfth centuries, there was a surge in the number of educated elites (pepaideumenoi in Byzantium and shi \pm in China) who constituted the basis of the imperial bureaucracy, and whose qualifications for office and standing in elite society depended on their learning and cultural mastery of the ancient, "classical « heritage. ${ }^{2}$ During this period, there was, in both cultures, heightened interest in Antiquity and in reflecting on what it meant. In China, here referring to the realm governed by the Northern Song 宋 Dynasty (960-1127), ${ }^{3}$ there was an important shift in the very conception of Antiquity, what it meant to learn from the ancients, and how to emulate the lessons of Antiquity in the present. ${ }^{4}$ In

1 For a synoptic overview of the transitions that characterized this period in Byzantium and China, respectively, see Kazhdan and Epstein, Change, and Chaffee, Introduction.

2 For an overview of the literati and their place in Byzantine administration, see Spingou, Introduction, l-lvi with further bibliography. For the Song system of education and bureaucratic recruitment through the examination system, see Chaffee, Sung education.

3 The Song is conventionally broken down into the Northern and the Southern Song (1126-1279) periods. For convenience, this paper will often speak generally of "Song " developments in referring to figures and phenomena of the Northern Song period.

4 For a concise treatment of the new paradigm of Antiquity that shaped the learning and ethical outlook of literati in Song China, see Bol, Neo-Confucianism in History, 52-72. 
Byzantium, scholars expanded the canon of classical texts from previous centuries, and engaged in active discussion with them, bringing past ideas to bear on the present. ${ }^{5}$ Such shifts gave rise to norms and values that also shaped the arts and aesthetic appreciation. They also form an important backdrop to the imagination of gardens during this period, and to the discourse of pleasure surrounding gardens.

Although Byzantine and Chinese discourses of pleasure in the garden were founded on markedly contrasting conceptions and practices of garden-building, as well as ideas about pleasure, in both cultures, the garden - alongside textual learning and engagement with the arts - had an important place among the cultural markers that sustained the collective identity of literati. Such markers of distinction had an ambiguous status insofar as they qualified literati for a place in the imperial system and provided avenues of participation in official life, but also offered a space in which to retreat from official life and enjoy a sphere of independence and autonomy. As physical objects but also as objects of discourse, they furnished the setting for sustained reflection among literati about their life predicaments, becoming, effectively, an alternate world in which to navigate one's path towards self-realization, and to fulfill one's »true nature« ( $\phi$ v́øı/ /xing 性).

The article is divided into four sections. The first section lays the groundwork by discussing the respective historical contexts of the flourishing of garden discourse in each culture, the different ways in which literati related to gardens (both physically and imaginatively), and the textual forms literati chose when writing about gardens. The two subsequent sections, focusing on the Chinese and Byzantine traditions respectively, investigate key eleventh- and twelfth-century writings on the theme of pleasure in the garden and the relevant classical antecedents to the discourse of pleasure. The final section recapitulates the major commonalities and differences between the discourses of pleasure in both traditions and draws out the insights arising from the cross-cultural exploration.

The discussion of Song literati discourses on the pleasure of gardens examines two well-known texts: Sima Guang's 司馬光 (1019-1086) »Record of the Garden of Solitary Pleasure (Du le yuan ji 獨樂園), and Su Shunqin's 蘇舜欽 (1008-1048) »Record of Canglang Pavilion “ (Canglang ting ji 滄浪亭記). Both written by literati who were forced into a life of retirement from public life, the two texts exemplify the way in which writing about one's garden became, in the Song period, a way to fashion one's literati identity and moral authority around the theme of pleasure.

The discussion on the Byzantine side focuses on two key sources from the corpus of late eleventh- and twelfth-century Byzantine literature: the first a romantic novel, Hysmine and

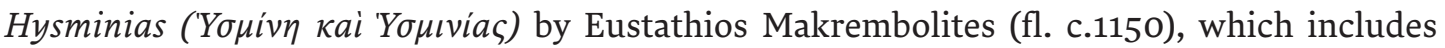
lengthy descriptions (ekphraseis) of a garden, and the second a series of epigrams, On a Garden (Eiৎ אĩnov), written by Theodore Prodromos (c. 1100-c. 1160). Both Makrembolites and Prodromos were based in Constantinople and had strong ties to aristocratic circles.

5 For a learned, discursive overview of the engagement with the "Classics« in the twelfth century, see Kaldellis, Classical scholarship and Kazhdan and Epstein, Change, 133-141. On the importance of Classicizing rhetoric, see also Gaul, Manuscript tradition, 78-79 with further references. The reader may also wish to consult Papaioannou, Michael Psellos, 166-170, on the discourse of Hellenism in the work of the paradigmatic author of the period, Michael Psellos. 
For all their differences, these sets of writings by Song Chinese and Byzantine literati were united by a shared vision of the garden as a place of antiquity, and as a site in which virtue could be realized through pleasure. They presented the garden as an arena in which to articulate and bring to fulfillment a vision of one's true and genuine self, and to make bold claims about what was the real basis of values and moral worth. In writing about their pleasure in these worlds of their own fashioning, the authors of these texts offered a testimony of their freedom and moral authority in the face of a vast political order upon which they depended, but that also required their participation and validation as the bearers of the authoritative classical tradition that sustained the very imperial project.

Writing the Garden in Byzantium and China: Contrasting Contexts, Practices and Genres Byzantine and Chinese discourses of pleasure in the garden during the eleventh and twelfth centuries present us with significant differences not only in the conception and discussion of pleasure, but also in terms of what the garden itself was, as a physical object and as a social, cultural, and political phenomenon. These differences shaped the ways in which literati related to the garden, both practically and as an object of reflection, aspiration and value. Moreover, by the eleventh century, the garden had long been a topic of literary and philosophical interest, and the distinct traditions that developed in each of these cultures continued to structure the content, approach and genre through which literati wrote about gardens, and about the pleasure they experienced in them.

In the Song period, beginning in the eleventh century, there was a flourishing of literary accounts of gardens, which corresponded to a major wave of garden-building among literati. ${ }^{6}$ Neither the ownership of gardens nor garden-building among literati was particularly new in this period: already from the Eastern Jin Period (317-420 CE) onwards, the garden featured as a prominent literary theme among such celebrated poets as Tao Qian 陶潛 (365?427, also known as Tao Yuanming 陶淵明) and Xie Lingyun 謝靈運 (385-433), who were both owners of gardens. Gardens became an even more visible feature of cultural life during the Tang Dynasty (618-907), when the construction and representation of gardens became an increasingly important pastime among imperial and aristocratic elites. ${ }^{7}$ However, literati from relatively modest backgrounds, like the famous poet Bai Juyi 白居易 (772-846), are also known to have owned gardens. ${ }^{8}$

6 For English translations of literary accounts of gardens from the Zhou Dynasty (1045-256 BCE) through the Qing dynasty (1644-1911), see Hardie and Campbell, Dumbarton Oaks Anthology of Chinese Garden Literature.

7 The growing number of imperial and aristocratic garden estates within commuting distance of Luoyang, the Tang's eastern capital, and in Chengnan, the region south of the imperial capital of Chang'an, gave rise to the emergence of what Stephen Owen has called the »Tang estate poem « during the eighth century. See Owen, Formation, 39-59. For a brief history of royal and imperial gardens and parks prior to the Song period, see Hargett, Huizong's magic marchmount, 1-5.

8 On the poetics of garden-writing in Bai Juyi, see Yang, Metamorphosis, 11-90. 
The trend toward private ownership continued on a wider scale during the Song period, when, alongside major social, political and economic developments, a sizable literati class came to power and prominence. ${ }^{9}$ These literati possessed the means to purchase and maintain private gardens, as well as the learning and culture to transform them into spaces of refined social interaction and objects of literary interest. Further contributing factors to the popularity of gardens were the demographic shifts and growth of urbanization that took place during this period: with the surge in population in the major urban centers of the Song empire, ${ }^{10}$ city-dwellers longed to escape from the crowded, polluted, cramped quarters in the city, and find a refuge in which they could enjoy the tranquil and beautiful surroundings of rustic, unspoiled nature.

The emergent discourse of pleasure in the garden was thus, to some extent, due to the sheer proliferation of privately-owned gardens, and to greater opportunities for the cultivation of private life and to the enjoyment of personal pleasures. But while historians have rightfully argued that the flourishing of literary and artistic activity surrounding gardens reflect a heightened interest in the realm of the private, ${ }^{11}$ such activity should also be understood as socially embedded forms of cultural construction that involved more than the physical reality of the garden itself, or enjoyment of the private sphere. In Song China, writing about gardens provided literati the opportunity to fashion, as some scholars have emphasized, an identity for themselves for public display - a public that defined itself through shared wen 文 (in this context, meaning "culture", "civilization «, "writing", or »literary attainment «). ${ }^{12}$ In the Northern Song period, the expansion of the class of educated and cultured elites ${ }^{13}$ resulted in the flourishing of the kinds of activities that these elites enjoyed and valued, and in new dynamics of social interaction among those literati taking part in these activities. In such a setting, owning a garden and writing about it became an important way to participate and display one's membership in the community of learned elites.

9 On the rise to prominence of literati during the transition to the Song period and the large-scale transformations behind this development, see Bol, "This Culture of Ours«, 32-75.

10 For a summary of major developments, see Hartman, Sung government and politics, 22-24.

11 The categories of the "private« and "personal« are central in Robert Harrist Jr.'s work on Northern Song painting and gardens. See esp. Harrist and Li, Painting and Private Life, 4-10, and Harrist, Art and identity, 151-153. The theme of the "private« is also emphasized in Yang, Metamorphosis, 2-4 and 249-251.

12 The term wen has a very expansive semantic range, originally referring to patterns in the natural world and, in the human context, »cultural accomplishment " (following Martin Kern) before becoming associated with text and writing during the transition to the Han 漢 dynasty (206 BCE-220 CE). On the early meanings and development of wen see Kern, Ritual, text.

13 Chinese historiography traditionally characterizes the transition from the Tang to the Song Dynasty as one in which military power ( $w u$ 武) gave way to civil (wen 文) authority, signaling the rise to prominence of an educated elite whose access to office and high position was determined by their achievement in learning, as measured by one's success in the civil service examinations. For an in-depth discussion of the debates in the early Song court leading to the dominance of wen, as defined by the proponents of ancient learning (guwen), see Bol, »This Culture of Ours", 148-175. 
But owning and writing about gardens were highly charged activities, both ethically and politically. And it was not a coincidence that some of the most well-known Song writings, including those examined here, were written by literati who were ousted from their official posts, or were in voluntary retirement from political life because of an inhospitable climate - an especially common fate among those caught up in the political turbulence surrounding the reform movements of Fan Zhongyan 范仲淹 (989-1052) and Wang Anshi 王安 石 (1021-1086). ${ }^{14}$ In such politically fraught times, to write about the joys and pleasures to be found in the garden allowed not only for the fashioning of one's identity, but also for the articulation of one's values and convictions. But given the wide-ranging forms and ethical ramifications of pleasure, this also involved a deliberate and delicate act of negotiation: in an age of commercialized wealth and a growing consumerism that seeped into all aspects of cultural life, there was much anxiety about the dangers of pleasure as well. The effort among some Song literati to link pleasure to virtue, then, marks a concern with identifying a legitimate realm of pleasure that was distinct from its potentially corrupt (and corrupting) forms. It was also directed towards showing that the locus of value lay within the self who appreciated such pleasure. Thus, for figures like Sima Guang and Su Shunqin, the pleasure that they experienced in their garden became the ultimate confirmation of their virtue. ${ }^{15}$

Both widespread ownership of gardens and new ways of relating to them had an impact on the literary form through which literati wrote about their gardens. Although Song literati writings about gardens took diverse forms and encompassed a variety of prose and poetic genres, a notable development in the Song period was the prevalence of $j i$ 記 - a short prose genre, commonly translated as "record« or "account«, that was often used to describe sites (natural or constructed), works of art, or other kinds of objects, as well as to narrate personal experiences. ${ }^{16}$ Some of the most famous and widely circulated texts about gardens in the Song period took the $j i$ form, and were highly self-referential and autobiographical. These "records" were thus not just factual, but also contained reflections about one's thoughts and feelings about gardens, or about topics of a more philosophical nature that were occasioned by the garden. They were also very much bound up with the identity of their owners. As Robert Harrist Jr. has put it, "the Northern Song bequeathed to later periods the conviction that a garden, like a piece of calligraphy or a painting, was in some essential way an extension of the identity of the person who created it. $\aleph^{17}$

14 On Fan Zhongyan's reforms, see Liu, Early Sung reformer, and McGrath, Reigns; on Wang Anshi's New Policies, See Bol, Government, society, and state; and Bol, "This Culture of Ours", 212-253.

15 John Makeham has emphasized the difficulty of distinguishing between aesthetic and moral discourses in the Chinese tradition, specifically in the context of gardens. See Makeham, Confucian role of names.

16 Tian, Collections, 229.

17 Harrist, Art and identity, 147. 
The Byzantine garden, by contrast, was not a private space, as gardens were usually shared spaces in monasteries and palace complexes, or in imagined worlds (designed to be shared through the performance of the narration).$^{18}$ Despite complaints about the turbulent life in Constantinople, evidence for privately owned gardens is rather limited, with the most famous example being that of John Geometres (fl. second half of the tenth century) and of Theodore Metochites (1270-1332). ${ }^{19}$ There is nothing surprising per se about the fact that there were such few private gardens owned by by twelfth-century literati, given their often low financial stature. Being a literatus may have ensured for most a position in the imperial bureaucracy, but it is quite questionable whether any income from that position would have sufficed to acquire and maintain a sizeable estate. That said, Byzantine literati were able to claim a form of ownership by writing about a public or fictional garden. When writing about gardens - be they fictional or real - they did not assume the point of view of its builder, but rather, selected elements they themselves deemed important or interesting, thus transforming a public space into a personal experience. Such personal views of the garden multiplied after the middle of the eleventh century, with descriptions of not only extant gardens but also fictional ones.

Given the very different kind of relationship that literati had with the gardens they wrote about, the rhetorical forms used to discuss them were also quite different from those prevalent in Song China. In contrast to the more self-referential records that were penned by their Song literati counterparts, in Byzantium, writings about gardens primarily took the rhetorical form of ekphrasis. ${ }^{20}$ An ekphrasis describes creative reflections on an extant or fictive sensual stimulus. The genre was developed by authors of the Second Sophistic (an intellectual movement that flourished between the second and third centuries CE and was influential during Late Antiquity) in the form of rhetorical exercises (the so-called progymnasmata). ${ }^{21}$ Telling in that respect is the Ekphrasis of a Garden, attributed to the famous rhetor Libanios, who lived in fourth-century CE Antioch and who became a model for later rhetoricians. ${ }^{22}$ His ekphrasis begins by praising the Homeric Phaeacians for owning the garden par excellence in Greek literature: that of Alcinous in the Odyssey. ${ }^{23}$ In what follows, Libanios tours that mythical garden describing what he had "seen«. He speaks of "low-lying" vegetation with streams running "from the mountains", surrounded by a stone wall. He also vividly describes

18 For an overview of the forms of Byzantine gardens see, e.g., Littlewood, Gardens of the Byzantine world, with references to both literary and archaeological records.

19 On Geometres' garden, see the excellent discussion in Demoen, Homeric garden, and Demoen, Classicizing elements. The relevant texts are edited in Littlewood, Progymnasmata, 7-13. On Metochites' garden, see Constantinides, Byzantine gardens and horticulture, 99-100. For a new edition of the relevant poem (no. 19), which was written after Metochites was forced into exile and his palace was destroyed, see Theodore Metochites, Poems, ed. Polemis, trans. Polemis, Theodore Metochites, Poems, 320.

20 On Ekphrasis, see, e.g., Elsner, Introduction, and Nilsson, Ekphrasis, both with further bibliography

21 The bibliography on the subject is vast. For a short and recent overview, see Nilsson, Raconter, 139-145. On the second sophistic, see, e.g. Fowler, Second Sophistic, and Goldhill, Rhetoric.

22 Ps. Libanios, Progymnasmata, 12.9, ed. Foerster 8, 485-486, trans. Gibson. On the authorship of the ekphrasis, see Gibson, Libanius' Progymnasmata, 427-428.

23 Odyssey, 7.53-68 and 112-131. See Nilsson, Erotic Pathos, 100, 211 and 263-264. 
a fertile land with blooming trees and rich produce, and birds whose singing pleases the ear of the beholder. Libanios finishes his ekphrasis emphasizing that what he described is not necessarily true, but the beauty of the words is more important than the vision: "It was possible to see these things with pleasure, but more pleasurable to describe them to the listeners. ${ }^{24}$ This ancient form for demonstrating rhetorical artistry would return in the twelfth century to give pleasure to an aristocratic audience interested in high rhetorical forms. ${ }^{25}$

Within a climate that encouraged inquiry on rhetoric and its ancient past, authors started again composing literary works in the form of novels. ${ }^{26}$ Romantic novels started to be written in Greek in the first century CE, but their production peaked in the second century, and the last example dates from the sixth century. One of the finest examples of this genre is The Adventures of Leukippe and Kleitophon by Achilles Tatius (second century CE), which narrates the turbulent love of a young couple. A small cluster of four novels re-emerge in the twelfth century. These novels were clearly influenced by ancient models, and one of them, namely Hysmine and Hysminias by Eustathios Makrembolites, is at the center of our analysis. ${ }^{27}$ Makrembolites was an imperial secretary in the 1140 os or 50 s when he composed his novel, but he would be promoted to high posts in the imperial administration shortly afterwards. ${ }^{28}$

Epigrams on works of art was another rhetorical form that literati often employed in discussing gardens. Epigrams were usually (but not necessarily) short texts that were inscribed or meant to be inscribed on actual works of art or on buildings, including those located in gardens and on their surrounding walls. ${ }^{29}$ In contrast to ekphraseis, which were only to be performed in a group of literature-loving peers, epigrams often served a more public function, with literate passers-by being invited to access and rehearse the texts. The epigrams on gardens focus on a specific feature of the garden, suggesting to the viewer how it should be understood. The text discussed below, a five-stanza epigram (or cycle of epigrams) called On a Garden by Theodore Prodromos, does not focus on a particular object or building in the garden as many epigrams did, but on a garden itself. Theodore Prodromos is perhaps the most prolific among literati in the twelfth century although, unfortunately, it is impossible to date the particular text. Given also that the text only survives in manuscripts (like the one quoted above), it is unclear whether it was ever inscribed on the walls of a garden or was only recited aloud to please listeners.

25 On twelfth-century ekphraseis, see Nilsson, Raconter, 152-158 and Nilsson, Ekphrasis.

26 See Nilsson, Romantic love; and Nilsson and Zagklas, »Hurry up«, for the constant presence of novels in Byzantium. For a list of descriptions of gardens in ancient and medieval romances, see Littlewood, Romantic paradises, $110-114$.

27 The main passages on gardens in Hysmine and Hysminias are 1.4-6, 2.1-11, 3.8 and 4.4-20. The relevant passages from Hysmine and Hysminias are discussed by Alicia Walker, Domestic gardens.

28 Jeffreys, Four Byzantine Novels, 159-165.

29 For an introduction to the genre of epigrams on works of art, see Spingou, Epigrams on works, with further references. 
Finally, there were also telling contrasts in the physical features of gardens in Byzantium and China. Writings about gardens in Song China suggest that they were varied in size, usage and layout, ranging from the sprawling, lavish, and built spaces of the vast estates owned by the emperor and the nobility, to more modest ones owned by individuals of more humble means, for whom the garden could also be a source of subsistence. But if there is no set model of a »Chinese garden ${ }^{30}$ or even a typical Song literati garden, it is possible to glean certain shared features and aesthetic values based on descriptions of gardens that emerged during this period. Li Gefei's 李格非 (c. 1041-1101) »Record of the Famous Gardens of Luoyang" (Luoyang ming yuan ji 洛陽名園記) ${ }^{31}$ provides descriptions of varying length and detail of nineteen gardens in the old capital city of Luoyang, among them Sima Guang's famous »Garden of Solitary Pleasure«. Notable, recurring features of these gardens include the prevalence of terraces, pavilions and hills, from which one can visually take in the expanse of the garden or the surrounding areas; a preponderance of water - ponds, streams, and lakes; winding pathways; and an abundance of vegetation - unusual or exotic plants, or else groves of bamboos or other kinds of trees. The type of garden described in the cases considered here is simple, rustic and minimally built, with simple architectural structures, groves of trees, and access to water and open spaces. This type sustained the idea of the garden as a natural and pristine realm that offered a respite from the tedium and oppressiveness of life in the urban centers. ${ }^{32}$

The classical Chinese terms for gardens - most commonly yuan 園, but also $p u$ 固, which often involves a vegetable garden, and you 直, a walled park - are all characters graphically inscribed with boundaries, and carry an early association with enclosures, which represents a striking parallel to the walled enclosures emphasized in Byzantine writings about gardens. ${ }^{33}$ Despite the fact that most Song literati gardens were constructed within the city walls and were also enclosed spaces, literati often described their gardens as open sites with porous boundaries between the world inside and outside the garden, and with elevated platforms for taking in expansive views. ${ }^{34}$ This physical openness had important social, political and cultural ramifications, providing the space and the occasion for literati to visit each other,

30 As Craig Clunas emphasizes in Fruitful Sites, 9-15.

31 The text has been preserved in numerous text collections, including the eighteenth-century compendium, Siku Quanshu 四庫全書, and the Congshu jicheng 叢書集成. The version consulted here appears in the former collection, in a set of writings called the Gujin yishi 古今逸史, compiled in the sixteenth century by the Ming dynasty collector Wu Gun 吳琯 (b. 1545). A full translation and study of Li's text by Kenneth J. Hammond can be found in Campbell and Hardie, 222-232, in Watson, »Famous Gardens«, and in Yang, »Luoyang Ming yuan ji«.

32 The "naturalness" of these gardens, as will be further elaborated below, was very much by design. This was the case not only of the gardens themselves, but of the discourse surrounding gardens. As Yang Xiaoshan has underscored, "naturalizing the garden did not mean letting nature take over; on the contrary, constructing a garden was a rigorous process of subjective control and selection. "Yang, Metamorphosis, 4.

33 Lin, Good place, 127.

34 As Philip Watson has stressed in the introduction to his translation of this text, this openness - and its emphasis in Song sources - represents a marked contrast from the gardens of the late Ming (1368-1644) and Qing (1644-1911) periods, which featured walled enclosures, and which marked off gardens as private, hidden, and domestic spaces. Watson, »Famous Gardens«, 41. 
strengthen their connections, and engage in those activities that literati during this period came to value and identify themselves with, such as learned conversation, reading and studying, writing, drinking tea, and appreciating beautiful things - including the garden itself. ${ }^{35}$ Moreover, like their lavish imperial counterparts which were open on festival days, and which were important sites of entertainment, consumption and celebration, literati gardens in Song China were also open to the wider public on certain days of the year. This made them a part of the public landscape of the city and its surroundings, and a fixture of the cultural imagination. ${ }^{36}$ On some occasions, the literati carrying on in the gardens was itself the spectacle, as attested by the following observation by Shao Bowen 邵伯温 (10571134): $:{ }^{37}$ "Luoyang has many famous gardens and ancient temples, filled with waters, bamboos, groves, and pavilions. Whenever the elders gathered, with their snow-white eyebrows and their magnificent attire, everyone followed to watch them. ${ }^{38}$

At the same time, the emphasis on the experience of open views in Song Chinese gardens as a pleasurable feature of gardens was linked to the garden's role as a refuge and a realm apart - a place in which one could dictate the terms of one's physical and moral existence. The lofty structures and elevated platforms that afforded panoramic views were important emblems of what the garden signified for those literati who retreated to them and, just as importantly, wrote about them: namely, a place in which one could rise above the ordinary confines within which one found oneself and achieve a higher vantage point - with all of the ethical and epistemological implications that such a position entailed. The possibility of climbing to a height or positioning oneself so as to achieve a privileged visual position was, in turn, part of a more general descriptive strategy in which the garden's significance derived not only from its features and from the objects it contained, but also, as we will see below, from the way that it functioned as an arena through which one could navigate, thereby exercising one's agency. ${ }^{39}$

35 The fact that Li Gefei wrote a »record« of famous (ming 名) gardens in Luoyang is one of the most revealing documents of the way in which literati visited and partook of the pleasures of each other's gardens, and shared their thoughts and experiences of them in their writings, thus participating in a shared literati subculture revolving around gardens.

36 West, Spectacle, ritual, 291-293.

37 Shao Bowen was the son of the famous Neo-Confucian natural philosopher and poet, Shao Yong, mentioned below. Shao is known for his work in editing and promoting his father's work, and for his book, Shao's Records of Things Seen and Heard (Shaoshi wenjian lu 邵氏聞見錄) which, among other things, describes activities surrounding gardens in Luoyang.

38 Shao Bowen, Records of Things, 10.105. See the discussion of this passage, and of the vibrant social culture surrounding gardens, in Yang, Metamorphosis, 220-222.

39 This way of approaching the garden was a basic feature of the aesthetics of landscape painting, which - not coincidentally - emerged during this period as the foremost genre of painting. A well-known feature of Northern Song landscape aesthetics is the idea that a landscape painting should endeavor to become a kind of virtual reality that would enable the viewer to imagine walking through the landscape. As Guo Xi 郭熙 (c. 1020-1090), one of the most famous Northern Song landscapists and landscape theorists put it, a properly executed landscape painting was one that created a space through which a viewer could enter. Guo Xi, Lofty Message of Forests and Streams Collection, juan 1.2a. 
A Byzantine pleasure garden was called keppos or paradeisos. In contrast to the open-view garden described in earlier texts, gardens in the eleventh and twelfth centuries were enclosed, heavily walled places. ${ }^{40}$ By the eleventh century, the kinds of pleasure gardens that drew the attention of the literati were enclosed urban spaces located in the empire's perennial capital, Constantinople. The prolific literatus Michael Psellos (1017/1018-1078 or 1096) writes about his admiration of the magnitude of the garden established by Constantine IX Monomachos (r. 1042-1055), but he does not neglect to mention that the emperor took special care to establish borders. ${ }^{41}$ The virtue of the garden as a guarded shelter was also conveyed through a series of metaphors, such as that of a trusted friend, who was called an »enclosed garden " referring to the security that hearty and honest communication offers..$^{42}$ Moreover, the enclosed garden, thanks to its physical appearance, is often interpreted in the male imagination as an enclosed landscape that contains a desirable woman, who stands far from the turmoil of life. ${ }^{43}$

Nonetheless, the wall of the Byzantine garden was used to define a unity consisting of beautiful parts, every single one of which was deemed essential for the aesthetic enchantment offered by the garden. ${ }^{44}$ The above-mentioned description of the imperial garden in Mangana emphasizes that

it was not merely the exceptional beauty of the whole, composed as it was of most beautiful parts, but just as much the individual details that attracted the spectators' attention, and although he could find pleasure in all its charms, it was impossible to find one that palled. Every part of it took the eye, and what is more wonderful, even when you gazed on the loveliest part of all, some small detail would delight you as a fresh discovery. ${ }^{45}$

The parts contained within a walled landscape surpassed their individual aesthetic power, and they create a proper whole - the Byzantine garden.

41 Michael Psellos, Chronographia, ed. Impellizzeri, 6.173, trans. Sewter, 190.

42 On the metaphor of a garden as a friend, see Gregory Antiochos, Letter to the Bishop of Kastoria, 1. 79-82, ed. Drakopoulou and Loukaki, 129.

43 Barber, Reading the garden, esp. 14-19; Della Dora, Landscape, 115; Stewart, Literary landscapes, $287-289$.

44 On the importance of the unity of parts in Greek aesthetics, see Heath, Unity, wholeness and proportion.

45 Michael Psellos, Chronographia, ed. Impellizzeri, 6.186, trans. Sewter, 190-191. 


\section{The Classicizing Garden and Pleasure in Northern Song China}

In the Chinese intellectual tradition, pleasure was a major topic of philosophical and literary interest long before the eleventh century. In foundational texts of the pre-Qin period (between the sixth and third centuries BCE), it figured prominently in ethical and moral psychological debates about the nature of the good life and how to realize it. It was also important in early theories of statecraft, where the problem of how to manage and satisfy the desire for pleasure - that of rulers, as well as of the people - was of central concern. Much of the discussion revolved around the term $l e$ 樂. Commonly translated into English as "pleasure«, but also as "joy", "delight", or "happiness", le covers a far broader semantic range than the English term "pleasure«, with its hedonic associations of sensual and bodily pleasure. ${ }^{46}$

Le appears in early taxonomies of emotions where it was part of a grouping of usually four, six or seven basic feelings (qing 情). ${ }^{47}$ The core four consisted of joy ( $x i$ 喜), anger ( $n u$ 怒), sorrow ( $a i$ 哀) and pleasure (le 樂) but the list was sometimes expanded to include fear ( $j u$ 懼), dislike ( $w u$ 惡) and desire ( $y u$ 欲)..$^{48}$ But prior to the emergence of such taxonomies around the fourth century BCE, and subsequently as well, le had a privileged status that went beyond its being simply one of the basic human feelings, ${ }^{49}$ and was often invoked as a criterion of the properly lived life. Thus, if early mainstream philosophical texts warned against taking self-indulgent forms of pleasure that were oriented primarily towards sensual gratification or excessive luxury, on the whole, the ethical status of le in these writings tended to be more positively oriented, and was often recognized as an accompaniment to virtue, rather than as a danger to it.

In the Analects of Confucius (Kongzi 孔子, 551?-479? BCE), and the Mencius (Mengzi 孟 子, $372-289 \mathrm{BCE}),{ }^{50}$ the early Confucian texts that would become most authoritative during the Song period, pleasure was connected to virtue in several ways. The framing of pleasure in these particular texts is worth underscoring because they would become important touchstones for many eleventh-century literati who wrote about the pleasures they took in their gardens. First, and most basically, pleasure was not something to be distinguished from virtue, but was part and parcel of what it meant to live a virtuous life. As Confucius declared, speaking of the Dao 道 (the Way, the true path of living), "One who knows ( $z h i$ 知) it is not the equal of one who loves (hao 好) it, and one who loves it is not the equal of one who delights (le 樂) in it. « ${ }^{51}$ In this respect, the very capacity for genuine pleasure accompanied the reali-

46 For a study of pleasure in the premodern Chinese intellectual tradition, see Nylan, Chinese Pleasure Book.

47 On the development and conceptual implications of the early mainstream philosophical account of emotions in China, see Virág, Emotions.

48 Virág, Emotions, 6. For a discussion of early taxonomies of qing, see Harbsmeier, Semantics of Qing.

49 As far as the existing evidence shows, this took place in around the fourth century BCE, and it is to this period that what can properly be called moral psychological theorization (and hence, a theory of »emotions «) can be traced. Virág, Emotions, 1-25.

50 Confucius is the presumed founder of the authoritative classical tradition in China and Mengzi (or Mencius) is widely recognized as the most influential among his latter-day followers. The Song period was marked by an intellectual revival of the early Confucian tradition as represented by the writings associated with these two figures. See Bol, "This Culture of Ours«, 176-188.

51 Lunyu 6.20, ed. Lau et al., 13/25. See the discussion of this and related passages about the importance of pleasure and delight in Confucius' ethics, in Virág, Emotions, 41-45. 
zation of a good life, and encompassed what it meant to live a life of true virtue. Second, the defining criterion of virtue was not so much whether or not one succumbed to pleasure, but whether one took pleasure in those things that were genuinely worthwhile..$^{52} \mathrm{~A}$ declaration of one's experience of pleasure in the proper things was thus tantamount to a declaration of one's virtue.

During the Song period, these early attitudes towards pleasure - articulated not only in early Confucian texts, but also in other writings like the early Daoist philosophical text, the Zhuangzi 莊子 (late 4th century BCE), as we shall see below - were actively invoked by Song thinkers, including Sima Guang and Su Shunqin. The appeal of these early accounts of pleasure can be explained, in part, by the fact that there was a heightened interest in emotional life more generally, as reflected in the preoccupation among writers and artists with emotions as an explicit topic of theorization and discussion. ${ }^{53}$ But pleasure in the northern Song period had a significance that extended beyond its inclusion among the various »emotions". The ways in which some Song literati sought to delineate the boundaries of this pleasure and to offer a defense of "virtuous" pleasure suggests that the topic was a site of controversy. As Ronald Egan observes, there was, in Northern Song aesthetic culture, a deep ambivalence surrounding aesthetically pleasing objects - an ambivalence that played out in writings relating to gardens. ${ }^{54}$ This is exemplified by the afterword to Li Gefei's »Record of the Famous Gardens of Luoyang" which provides a sobering reminder of the harms that could befall the empire if the wealthy and powerful continue to indulge themselves in the extravagant pleasures provided by their lavish gardens. What is striking about this text, Egan observes, is the fact that Li's condemnation of pleasure-taking in one's garden could follow such an exuberant account of the beauty and wonders of the most celebrated among the gardens in Luoyang. ${ }^{55}$

52 See, e.g., Lunyu 16.5, where Confucius makes a categorical distinction between good and bad forms of pleasure by identifying those pleasures that are beneficial (yi 益) and those that are harmful (sun 損). ed. Lau et al., 46/8-9.

53 This is a pervasive phenomenon that can be seen in wide-ranging domains of intellectual life during the Song period, and was evident not only in the prevalence of more personal, informal, and autobiographical writings (of which accounts of gardens was just one example), but also in the heightened interest in moral psychology and self-cultivation that characterized philosophical discourse during this period. In all these domains, this development went hand in hand with an emergent ethical position that tended towards the recognition of the importance of emotions in moral life. On this, see Virág, Emotions and agency; Virág, Self-cultivation as Praxis; and Virág, Ethics of emotion. A synthetic treatment on this phenomenon in Song intellectual life more generally remains be written.

54 Egan, Problem of Beauty, 109-161.

55 Egan, Problem of Beauty, 160-161. As Egan recounts, Li's text later achieved fame because he was regarded by many as having predicted the loss of the north to the Jin Dynasty (1115-1234), an event that has been traditionally understood as the result of precisely the kind of extravagant pleasure-taking that Li warned against in his text. 
This anxiety about the dangers of pleasure is an important part of the background to the more positive forms of pleasure emphasized by some Northern Song thinkers. If Li Gefei approached the matter by both embracing and condemning the pleasures of the garden, other writers sought to achieve a different sort of balance by delineating the proper scope of pleasure and binding it more closely with their identity and character. This was the strategy of some of the most prominent Northern Song figures, including Ouyang Xiu 歐陽修 (1007-1072), Shao Yong 邵雍 (1011-1077), ${ }^{56}$ Su Shi 蘇軾 (1037-1101), ${ }^{57}$ and Sima Guang 司馬光 (1019-1086)..$^{58}$

All of these thinkers wrote voluminously about the things they took pleasure in, and about their experience of pleasure. Some, however, took the further step of crafting a persona for themselves around the theme of pleasure. ${ }^{59}$ Ouyang Xiu famously took as his epithet the Retired Scholar of the Six Ones (Liu yi ju shi 六一居士), referring to those six objects that he took pleasure in: his books, bronze and stone inscriptions, zither, chessboard, jug of wine, and his own self. ${ }^{60}$ Others, like Shao Yong and Sima Guang, both owners of gardens in the old capital city of Luoyang, conferred the very word le on their garden estates, thus binding their experience of pleasure and enjoyment more closely to their literary identity. Shao named his garden estate "The Nest of Peace and Enjoyment (Anlewo 安樂窩) and wrote many poems describing the pleasurable circumstances of his life in retirement there, far from the cares of official responsibility. ${ }^{61}$ Sima Guang similarly constructed a "Garden of Solitary Pleasure" (Du le yuan 獨樂園) and wrote not only a famous prose account of it, but also a number of poems, including his "The Garden of Solitary Pleasure: Seven Songs" (Du le yuan qi ti 獨樂 園七題). ${ }^{62}$ Another famous "pleasure " garden was that of Zhu Changwen 朱長文 (1040-1098), whose Garden of Delight (Lepu 樂戋) was similarly the topic of a celebrated account called the "Record of the Garden of Delight « (Lepu ji 樂戋記). ${ }^{63}$

56 Shao Yong was a natural philosopher and poet most well-known for his endeavors to schematize and model the unity of the cosmos through a numerological system. His major work in this area was the Book of Supreme Principles for Ordering the World (Huangji jingshishu 皇極經世書), ed. Wei Shaosheng. Shao also produced a collection of poetry, the Collection of Beating the Earth by the Yi River (Yichuan Jirang ji 伊川擊壤集), ed. Okada Takeshi.

$57 \mathrm{Su}$ Shi was one of the most renowned intellectual figures of the Northern Song period. He was an important statesman, as well as a prolific and celebrated poet, essayist, scholar, calligrapher and painter. Su's close involvement in the factional struggles of the 1070s led to his banishment and exile to Huangzhou, where he farmed and continued writing on - among other things - the toils and joys of rural life. For an excellent literary biography of Su Shi, see Fuller, Road to East Slope.

58 Sima Guang was one of the most prominent literati figures in the eleventh century, and the leader of what we might call a conservative, anti-Wang Anshi faction in the court. On the different political visions of Sima Guang and Wang Anshi, and their larger contexts, see Bol, Government, society, and state.

59 Xiaoshan Yang devotes a chapter in his study of Tang and Song garden culture to the theme of le, but approaches it in terms of a focus on joy and happiness during this period, as a reaction to past poetic sensibilities that presumably focused on sorrow. See Yang, Metamorphosis, 197-242. On emotions in the ethical configuration of the self in Ouyang Xiu, Shao Yong and Su Shi, see Virág, "That Which Encompasses the Myriad Cares".

60 Ouyang Xiu, Ouyang Xiu Quanji, ed. Li Yi’an, 634-635.

61 Shao Yong's estate was a gift to him by devoted friends in high positions, and it enabled him to live out his days in retirement. See Yang, Metamorphosis, 222-226.

62 In Sima, Sima Gong Wenji, juan 14. James M. Hargett's translation of these poems appears in Campbell and Hardie, 207-209.

63 Despite his early success in the state examinations, a foot injury kept Zhu out of office, and he spent much of his adult life at home in his family estate and gardens. For a study of Zhu's garden within the backdrop of his personal, social and cultural circumstances, see West, Zhu Changwen. 
Sima Guang built his »Garden of Solitary Pleasure« in Luoyang in 1071, after being forced into retirement from political life in the wake of his conflicts with the radical reform policies of the Chief Chancellor, Wang Anshi 王安石 (1021-1086).$^{64}$ His "Record of the Garden of Solitary Pleasure ${ }^{65}$ is heavy with allusions to the early Confucian tradition, which allow him to identify his own pleasure in the garden with paradigm cases of pleasure in the Analects and the Mencius. The "solitary pleasure " $(d u$ le 獨樂) that furnishes the name for his famous garden is a classicizing reference to a passage in the Mencius, but with an ironic twist, which gives a special charge to the meaning of the pleasure that Sima writes about in his account. The reference is to a series of exchanges that Mencius had with King Hui of the state of Liang, whom Mencius was trying to persuade to become a more benevolent ruler who provides for his people. In one exchange, the king, standing by a pond and surveying his vast domain, asks Mencius, "Do the worthy also take pleasure in these things? « To which Mencius replies, "Only the worthy take pleasure in these things. Those who are not worthy, even if they have these things, do not take pleasure in them. ${ }^{66}$ To explain what he means, Mencius makes a classicizing reference of his own, quoting a passage from the ancient classic, the Book of Odes (Shijing 詩經), about the virtuous King Wen, whose pleasure in his estate was made possible by the fact that he shared his pleasure with his people. When King Wen constructed a tower and pond on his estate - effectively making it a place designated for enjoyment - the common people participated in the construction, and so the king invited them to enjoy the place with him. As Mencius reports,

King Wen, with the strength of the people, made the Tower and made the Pond, but the people were pleased and delighted by them (huan le 歡樂): they called his tower the "Marvelous Tower«; they called his pond the "Marvelous Pond«; they delighted (le 樂) in its having deer, fish, and turtles. The ancients delighted in these things together with the people, hence they were able to delight in them. ${ }^{67}$

In the course of this exchange between Mencius and King Hui, Mencius articulates a number of crucial points about pleasure, both of which are of key importance for understanding the pleasure of which Sima writes in the context of his garden. First, there is nothing wrong with taking pleasure in things: no virtue is attached to asceticism here ${ }^{68}$ Second, pleasure is not just about the feeling of pleasure derived from beautiful things, but an earned capacity that only people of virtue can experience. King Wen's pleasure, in short, is a testimony to his virtue. Third, what qualifies King Wen's pleasure as true - and therefore virtuous - pleasure is the fact that he has shared it with his people. His enjoyment in the delightful park is made possible by the fact that he enjoys the delights of his royal domain with his people.

64 See footnote 11, above.

65 In Sima, Sima Gong wenji, juan 66. For a full translation of this text, see Hardie, Craft of Gardens, 122-123, and Campbell and Hardie, 204-206.

66 Mencius, Mengzi 1A1, trans. Van Norden, 2. Italics added.

67 Mencius, Mengzi 1A1, trans. Van Norden, 2-3. Italics added.

68 On Mencius' approach to pleasure within the broader framework of his conception of emotions, see Virág, Emotions, 101-132. 
When Sima builds himself a garden and calls it "The Garden of Solitary Pleasure, " he explicitly departs from the standards of virtuous pleasure promoted by Mencius. He insists that they apply only to kings and rulers, and not to people of modest means like himself. But the direction in which he takes the discussion suggests that Sima's assertion of his solitary pleasure is more than about the simple joys of his humble circumstances: it is also about the fissure that has developed in the political world, such that the center no longer binds the whole together. Sima thus looks elsewhere for models of pleasure that are more appropriate to his own situation and finds them in 1) the pleasure of Yan Hui, the favorite disciple of Confucius; and 2) the simple, natural pleasure of animals subsisting in nature.

The first is a reference to passage 6.11 in Confucius' Analects, where the Master praises Yan Hui for dedicating himself to a life of learning and virtue, despite having to endure great hardship. What is praiseworthy in Yan Hui is not the sheer fact that he chose to live this way, but that, in so doing, he managed to keep his pleasure intact: "What a worthy man was Yan Hui! Living in a narrow alley, subsisting on a basket of grain and a gourd full of water - other people could not have born such hardship, yet it never altered his pleasure (le 樂). What a worthy man was Hui! «99 For Confucius, Yan Hui's pleasure is the mark of his true and authentic virtue. Confucius' celebration of Yan Hui's undiminished pleasure in the midst of his impoverished circumstances serves as an important reference point for Sima, whose own pleasure in his garden allows him to identify with Yan Hui's virtue. The second model that Sima invokes - the pleasure of the animals in the natural world - is a reference to the early philosophical Daoist text, the Zhuangzi. Attributed to a figure called Zhuang Zhou 莊周 (c. 356-286 BCE), this text promotes an ethical ideal founded on spontaneity and naturalness. Like many other Song thinkers, Sima appeals to this text to express and confer authority to his alternative vision of virtue outside of life in politics. In the original Zhuangzi passage, which appears in its opening chapter, titled "Free and Unfettered Wandering " (Xiao yao you 逍遙遊), the bird and mole are invoked by a hermit called Xu You, to whom the ancient sageking Yao offers his throne. Xu You declines the offer, comparing himself to the bird and the mole who, though possessing nothing more than a branch for building one's nest and water to drink from the streams, are able to remain perfectly content. ${ }^{70}$ Citing this passage, Sima concludes that "each is content with its lot ${ }^{71}$ and that he, with his garden, has also found contentment in his own humble circumstances. In thus drawing attention to his pleasure, Sima claims that he, like Yan Hui and Xu You, possesses the fortitude and moral integrity to enjoy the pleasures of his circumstances.

69 Confucius, Lunyu 6.11, trans. Slingerland, 56.

70 Zhuangzi Ch. 1, ed. Lau et al., 1/2/10-1/2/11.

71 Sima, Sima Gong wenji, juan 66. 
In addition to framing his own virtuous pleasure in terms of his chosen ancient exemplars, Sima's account of his garden reveals another way in which the authoritative classical tradition comes into play in making a virtue out of pleasure. Like many other gardens during the Song period, Sima's was a classicizing garden in the additional sense that its space was given coherence and meaning through the naming of sites that referred to exemplary figures and events from the distant past. ${ }^{72}$ Sima's garden contained seven different sites, each corresponding to a revered figure from the past, and whose claim to virtue was captured in the activity that gave its name to the site ${ }^{73}$ :

1) The Reading Hall (Dushu tang 讀書堂): named for Dong Zhongshu 董仲舒 (c. 179104 BCE), the learned scholar who promoted Confucianism in the Han imperial court.

2) The Fishing Hut (Diaoyu an 釣魚庵): named for Yan Guang 嚴光, the friend of Han Emperor Guangwu (r. 25-26) before he ascended the throne, who gave up the chance for high office and chose, instead, to live as a hermit and spend his life fishing and farming.

3) Gathering Herbs Patch (Caiyao pu 采藥戋): named for Han Kang (fl. 147-167), an herb seller who fled renown and offers of high office.

4) Viewing Mountains Terrace (Jianshan tai 見山臺): named for Tao Qian 陶潛 (365427), the most famous and beloved of reclusive poets, who gave up an unhappy career as an official to live a simple life in the countryside. Tao Qian's legacy was revived by Song writers, many of whom identified with his plight.

5) Dallying With Water Gallery (Nongshui xuan 弄水軒): named for Du Mu 杜牧 (803852 ) the late Tang writer and poet, who had a pavilion built with the same name.

6) Planting Bamboo Studio (Zhongzhu zhai 種竹齋): named for Wang Huizhi 王徽之 (d. 388), son of the legendary calligrapher Wang Xizhi 王羲之 (321-379), who loved bamboos and planted them around his house.

7) Watering Flowers Kiosk (jiaohua ting 澆花亭): named for the famous Tang poet Bai Juyi 白居易 (772-846), known for his love of flowers.

Having named these sites, Sima describes his experience of moving from one to the other, proceeding from the Reading Hall, where he studies the writings of the ancient masters, and then, tiring of that, going fishing or gathering herbs, tending to his flowers, or hiking up to a lofty perch from which to take in the views. Through the activity of moving through the

72 The significance of these named sites in Sima's garden is the topic of Robert E. Harrist Jr's illuminating article, Site names and their meanings. On the importance of naming in the Chinese tradition and its resurgence in the Song period, see Makeham, Confucian role of names. Makeham particularly emphasizes the role of naming in signaling participation in a community of "players « taking part in a shared performance.

73 Sima explains these references in his "Seven Inscriptions from the Garden of Solitary Pleasure ( Du le yuan qi ti 獨樂園七題). I follow Hargett's translation of these site names. For fuller descriptions of the sites and the figures associated with them, see Harrist, Site names, 209. 
various sites of the garden, each dedicated to a past figure whose virtues and pleasures he identifies with, Sima transforms his garden into a living landscape in which to commune with figures past, and to enact both his pleasure and his virtue. He concludes by describing how the garden becomes for him a place of freedom:

When I proceed, nothing pulls me along; when I stop, nothing brings me to a standstill; my ears and eyes, lungs and intestines are entirely my own and I rely on myself alone. I don't know what pleasure in the world can possibly match this, and therefore I call my garden the »The Garden of Solitary Pleasure. ${ }^{74}$

Sima's reference to the parts of his body is highly significant. For it is through his body, which is inalienably his own, that he experiences his freedom and the possibility of self-realization. Even when politics has turned sour for him, when he has lost his place in society and in the court, his body remains his own, and he does with it as he wills. This attention to the workings of his own body reveals the further significance of the garden and its pleasures for Sima: the garden offers a home for his body to roam freely and achieve what it needs, thereby allowing him to realize his genuine pleasures. Beyond merely providing an account of a man enjoying his garden, Sima's testimony of the pleasure he has achieved in his garden is a defense of his own self-worth, independence and autonomy.

The theme of the garden as a place in which to realize one's agency and freedom through the workings of the body is also prominent in Su Shunqin's 蘇舜欽 (1008-1048), "Record of Canglang Pavilion «. ${ }^{75}$ The narrative begins with Su's disclosure about how, having been dismissed from his official post, he comes to purchase the plot of land that would eventually become his famous garden. This crisis, which unanchors him from a position of stability and leaves him without a place to call home, sets him on a path of wandering. After a period of both geographical dislocation and psychic and emotional frustration, Su eventually finds a deserted plot of land, covered with bamboo groves, and purchases it for 40,000 strings of cash. He builds a pavilion on the south bank of the stream, and calls it Canglang 滄浪, or the Azure Pavilion.

Having related the sequence of events leading to his procuring of the plot, Su devotes a few lines to describing the natural enchantments of the place, but the rest of the account is notably autobiographical: it tells of what happened to him upon his arrival at the property; how he sang while drinking and laughed out loud by himself, with only the birds and fish to share his pleasures (gong le 共樂); and how he came to reconnect to what one might call his true self through the experience of the simple pleasures of his body. As Su explains, it is through the body that one can realize the proper way to live and understand the world: "If the body (xing 形) attains what is proper to it, the spirit (shen 神) is not vexed; if what one sees and hears is not depraved, then the Dao is illuminated. ${ }^{76}$ This focus on the body and its engagements with real objects in the world reveals a crucial dimension of Su's conception of the self, and the human being more generally - namely, that we are emotional beings that need to lodge our emotions in the proper objects of concern:

75 Su, Su Xueshi Wenji, juan 13. Xu Xinong's translation and introduction of this text can be found in Campbell and Hardie, 245-247. See also Xu, Interplay of image.

$76 \mathrm{Su}$, Su Xueshi Wenji, juan 13. 
Ah! Humans are indeed sentient beings. The affections (qing 情) can so teem within one that one's true nature (xing 性) lies concealed; this true nature only finds its expression when the affections are lodged in things external to oneself. But if one's affections remain lodged there for too long, one can become obsessed with these external objects, and that lodgment becomes second nature. Unless one overcomes this situation and transfers [the affections to their proper concerns], one will be full of grief and frustration (bei er bu kai 悲而不開). ${ }^{77}$

In accordance with this account of the workings of human emotions, the garden becomes, for $\mathrm{Su}$, the arena in which his fundamental needs - what is proper to his emotional, psychological, physical and moral well-being - are fulfilled. And the pleasure that he achieves in the garden is his self attaining what is proper to it. This pleasure is what testifies to his realization of the Dao - a process that is, paradoxically, described as one of »self-overcoming " $(z i$ sheng 自勝).

The "self" that is overcome here is precisely the self that is captivated by the allure of glory and success in one's career. This is a direct reference to a passage in the canonical early Daoist text, the Daodejing, which states, "One who knows others is wise; one who knows oneself is intelligent; one who overcomes others possesses strength; one who overcomes oneself is powerful. « $^{78}$ It is, paradoxically, by overcoming oneself - that is, one's desires and longing for glory, power and advancement - that one can achieve real, worldly strength and power. For Su, then, to devote one's life to the pursuit of glory in one's career and take part in the competition for worldly success is problematic, not because it will lead to failure in achieving these goals, but because it will destroy one's person. To pursue the path of an official is to live a life of unfulfilled desires and passions, which will inevitably lead to grief and frustration. Su's claim is that his dismissal from office is what has allowed him to "overcome himself « and enjoy a peaceful life of tranquility - a life that has been made possible by his garden. The pleasure that he achieves there, in his alternative, private world, both enables and testifies to his realization of his most fundamental human aspirations. The garden opens the possibility of living a more natural and authentic existence, and of achieving freedom in a world of his own making. The vehicle of this freedom is ultimately his own self - a self that delights in the free and proper functioning of his body through its experience of pleasure in the garden.

\section{The Pleasures of Classicizing Learning in the Byzantine Garden}

Byzantine writings about pleasure and the garden are not as detailed as their Chinese counterparts. Nonetheless, the garden had consistently been a locus amoenus (an idealized place where one loves to be) since at least the second century, and, as such, it indulged the beholder with its enchantments. ${ }^{79}$ References to such loci amoeni multiplied after the middle of the eleventh

$77 \mathrm{Su}$, Su Xueshi Wenji, juan 13. Translation adapted from Xu, in Hardie and Campbell, 245-247.

78 Laozi, Laozi Deodejing, juan 33.

79 And not only in Greek literature. See about the garden as a locus amoenus in, e.g., the Latin literature in Myers, Docta Otia; Henderson, Hortus; Pagán, Rome. The term locus amoenus was introduced by E. R. Curtius in the mid50 (Europäische Literatur, 191-209). For modern treatments of the term see Hass, Der locus amoenus; Schönbeck, Der Locus, and the most remarkable collection of studies edited by Renée Ventresque, Le locus amoenus: variations autour d'un paysage ideal. I am most grateful to Yannis Papadogiannakis for suggesting Ventresque's book. 
century and during the twelfth century. Crucially, gardens were now falling within the purview of personal space. They were complex landscapes able to reveal the virtuous nature of their beholders (owners and visitors alike). In the context of a general, more vigorous interest in the self during the eleventh and twelfth centuries, ${ }^{80}$ it comes as little surprise that the garden was transformed into a personal locus amoenus, granting different forms of pleasure to its maker, beholder and reader.

Pleasure was a pathos for the Byzantines. Pathe (sing. pathos) is the Byzantine concept closest to the modern term "emotions". A pathos befalls someone, thus causing different responses according to the beholder's ethical disposition. ${ }^{81}$ Like any pathos, pleasure has a negative potential (called apolausis in our period) and a positive one (named terpsis/terpolè, and its near synonyms hédonè, thymédia, charmoné and charis) ${ }^{82}$ The term apolausis indicates an excessive drive to experience pleasure, while its direct opposite, terpsis, signifies a moderate interest in pleasure. Terpsis and its synonyms are inescapably connected with practicing a virtuous lifestyle. The distinction between terpsis and apolausis is exemplified in the discussion of gardens and their relation to their creators. The garden of Digenis Akrites, a Byzantine epic hero living near the River Euphrates, is praised as terpnos - that is, it is characterized by terpsis. ${ }^{83}$ In contrast to the virtuous garden of a hero, the garden of Emperor Constantine IX Monomachos is characterized by apolausis. That is hardly surprising for an emperor who, according to Psellos, was governed by his pathe and thus accused of debauchery. ${ }^{84}$

The understanding of pleasure as a pathos is present already in the Platonic corpus, and its binary understanding - as something that can be ethically good or bad - is common in Antiquity. ${ }^{85}$ Despite the flourishing of hedonistic philosophy during the Hellenistic era, pleasure is rarely discussed systematically in Christian philosophy. A bishop in Syria, Nemesios of Emesa, composed one of the few systematic treatments of the topic in the late fourth century

80 On the so-called »emergence of individuality « after the middle of the eleventh century, see, Kazhdan and Epstein, Change, 220-230. For a more recent and complex discussion of the distinction between the self and the individual, see Lauxtermann, Poetry, 192-193. For the self in twelfth-century Latin Europe, see the seminal study by Carolyn Bynum, Did the twelfth century.

81 Hinterberger, Emotions (with further bibliography).

82 The word hèdone is also used for denoting a negative form of pleasure, but such instances are rare in the eleventh century. See, e.g., Michael Psellos, Ekphrasis or Allegory of Circe, ed. Littlewood, no. 33, 18-22, transl. Angelidi, p. 288. The nuanced meaning of a term often changes with the passing of time. The terminology here is detailed using sources from the eleventh and twelfth centuries.

83 The garden of Digenis is described in a twelfth-century record of the epic, Digenis Akrites, Grottaferrata version, bk. 7, 8-44, trans. Jeffreys.

84 On the garden of Monomachos see above, 237. The description of the garden is included in passages expressing Kaiserkritik, see Ljubarski, E prosopikoteta, 310-315. In one of his letters, Psellos points out that the »apolaustikos vios" (pleasurable life) led to the downfall of the Roman imperium. On Kaiserkritik in the work of Psellos, see Tinnefield, Kategorien, 122-134.

85 For a detailed discussion of Classical, Hellenistic and Roman Imperial philosophical understandings of pleasure, the reader can refer to works such as, Destrée, Pleasure and Wolfsdorf, Pleasure, which includes a discussion of hedonistic philosophy. 
CE. In his treatise, On Human Nature, Nemesios, an Aristotelian thinker and a theologian, refutes hedonistic theories. ${ }^{86}$ Given that such a refutation of hedonistic theories would have been appropriate for Christian ethics, it remained relevant throughout the history of Byzantium. However, Nemesios' works had limited circulation in the twelfth century. ${ }^{87}$ Three centuries later, Maximos the Confessor (580-662), an original Christian thinker with a great command of Hellenic philosophy, attempts to explain the birth of pleasure in the human soul. ${ }^{88}$ He stipulates that pleasure is created through the combination of sensation and desire. As the sensible world is important in this understanding of pleasure, pleasure itself can move the soul towards the material world. The truly holy men receive a higher experience of pleasure. Practicing virtuous deeds, they transform that movement so as to adorn the body "with the beauty of divine manifestations « ${ }^{89}$ In other words, with the right experience of pleasure, human beings can come closer to God. Maximos the Confessor, whose work acquired popularity especially in the period under consideration, was heavily influenced by the work of Dionysius the Areopagite and Neoplatonism ${ }^{90}$ - a philosophical movement that flourished between the third and sixth centuries CE.

The interest in Neoplatonism during the late eleventh and twelfth centuries underpins an expanded vision of classicizing learning. Beyond subtle references to the Garden of Eden from the Jewish tradition, discussions of human gardens were traditionally "classicizing", referring to classical literary works familiar to all Byzantine school pupils, such as the Homeric epics. ${ }^{91}$ The reference to classical texts from the school curriculum is most clearly exemplified in the work of the tenth-century scholar John Geometres (c. 935-late tenth century). Geometres, who found refuge in his garden after he (probably) fell into imperial disfavor, took pride in the fact that his place of consolation did not simply resemble the garden of the mythical Alcinous from the seventh book of the Odyssey, but even surpassed it in beauty. ${ }^{92}$ References to the garden of Alcinous were ubiquitous in writings from later centuries, but later authors, seeking inspiration in philosophical works from the first to the sixth centuries CE, rediscovered "the garden of Zeus «, a reference to the Platonic Symposium that was further developed by the leading Neoplatonic philosopher, Plotinus (204/205-270 CE). ${ }^{93}$

86 As did many of his rough contemporaries. See, e.g., Gregory of Nazianzus, Moral Poems, in Patrologia Graeca 37: 736-737 or Against Julian 1 (Oration 4), Patrologia Graeca 35: 593; Nemesios, On Human Nature, ed. Morani, section 18; trans. Sharples and Van der Eijk, Nemesius, 134-139. Nemesios's treatise has been discussed in Walker, Apolausis. We are greatly indebted to Alicia Walker for allowing us to see a pre-publication version of her text.

87 Sharples and Van der Eijk, Nemesius, 4.

88 On Maximos the Confessor, see Booth, Maximos the Confessor, and Constas, On Difficulties in the Church Fathers, especially $\mathrm{x}$-xiii and xxii-xiii with further bibliography.

89 Maximos the Confessor, Ambigua (=On Difficulties) to John, Amb. 10.2b, ed. Constas, 160, transl. 161.

90 On Maximos' response to Neoplatonism (as compared to that of Dionysius the Areopagite) see Constas, The transformation of Christian Neoplatonism.

91 On the Christian Paradise/Garden of Eden in Byzantium see Maguire, Paradise withdrawn. On the garden of Alcinous see p. 235 above.

92 For the classicizing elements in Geometres' garden, see the discussion by Demoen, Homeric garden, esp. 120.

93 On Neoplatonic language, inspired by Pseudo-Dionysius the Areopagite, in Geometres' Ekphrasis on the basilica of the Stoudios monastery, see Maguire, Nectar \& Illusion, 127-128. 
Interest in classical works beyond those included in the school curriculum was expressed in the genre of romantic novels. That genre first flourished between the second and the fifth centuries $\mathrm{CE}$, but afterwards, the composition of novels ceased until the twelfth century. ${ }^{94}$ From the twelfth century, a small cluster of four romances connected to the Constantinopolitan court survives. Although references to gardens were rather limited in the ancient novels, they were more prevalent in their medieval successors. ${ }^{95}$ Eustathios Makrembolites' Hysmine and Hysminias is one of these medieval novels and is of particular interest for our discussion, given that it includes no fewer than four (shorter or longer) ekphraseis. ${ }^{96}$

Hysmine and Hysminias narrates the turbulent love of Hysminias, a herald sent from the fictional city of Eurykomis to the equally fictional city Aulikomis, and Hysmine, a noblewoman of Aulikomis. ${ }^{97}$ Early in the plot we read about the garden in the palace of Hysmine's father, Sosthenes. That garden was a place of antiquity: it contained no Christian landmarks, such as crosses or churches, but instead made references to antique columns, statuary and depictions of classicizing personified figures, such as the cardinal virtues or Eros. ${ }^{98}$ The description, in Hysminias's voice, begins thus:

This [garden] was full of cheering grace (charis) and pleasure (hèdonē), brimming with plants completely full of flowers. The cypresses are in rows, the myrtles form a dense covering, the vines are wreathed with grape clusters [...] Seeing this I thought I beheld Alcinous' garden and felt that I could not take as fiction the Elysian plain so solemnly described by the poets. For laurel and myrtle and cypresses and vines and all the other plants that adorn a garden, or rather that Sosthenes' garden contained, had their branches raised like arms and, as if setting up a dance, they spread a roof over the garden but they permit the sun to filter through to the ground in as much as the zephyr blew and rustled the leaves. When I saw this I said, "Sosthenes, you have woven me a golden chain. ${ }^{99}$

The opening sentence of this passage sets the tone for the rest of the description, starting with the two nearly synonymous words for pleasure: charis, implying charming pleasure, and hédone, adding an element of delight. The comparison to the mythical garden of Alcinous, the mythical ruler of the Phaeacians in the Odyssey, emphasizes the impact of the garden's beauties on the beholder. ${ }^{100}$ Aesthetic pleasure is also evoked with the flowery meadows, myrtles and dense tree canopies - a description that finds a parallel in Makrembolites' literary model, the first- or second-century CE novel Leukippe and Kleitophon by Achilles Tatius, and the Ekphrasis of a Garden by Libanios discussed above. ${ }^{101}$ The reference to the

94 See Nilsson, Romantic love; and Nilsson and Zagklas, "Hurry up«, for the persistent presence of novels in Byzantium. On the medieval novel, see Nilsson, Raconter, 57-86.

95 For a list of descriptions of gardens in ancient and medieval romances see Littlewood, Romantic paradises, 110-114.

96 Makrembolites, Hysmine and Hysminias, 1.4-6, 2.1-11, 3.8, and 4.4-20, ed. Marcovich. On the novel and the ekphraseis see Walker, Domestic gardens.

97 For a full summary of the plot see: Jeffreys, Four Byzantine Novels, 168-170.

98 Hysmine and Hysminias, I.5.2-6 and see below for the depiction of the personifications of the cardinal virtues and eros. Cf. the garden in Niketas Eugenianos (d. after 1158), Drosilla and Charikles, l, ed. Conca, 102-108, transl. Jeffreys.

99 Hysmine and Hysminias, I.4.1. and I.4.3-4, trans. Jeffreys, 179. The last word is translated as "cord« in Jeffreys.

100 Odyssey 7.112-131. On the specific passage Nilsson, Erotic Pathos, 86-99.

101 Achilles Tatius, Leukippe and Kleitophon, ed. Vilborg, 1.1.2-13. For the relation of Makrembolites' novel to that by Tatius, see Nilsson, Static imitation. 
"golden chain", which Hysminias claims Sosthenes had woven for him, is an indirect and simultaneous evocation of Neoplatonic cosmology and Christian ethics. Panagiotis Roilos has already underlined the connection of the particular passage with Neoplatonic texts, but below we revisit the argument and expand it in the context of the search for pleasure in the Byzantine garden. ${ }^{102}$

The "golden chain" is mentioned in the Iliad as the chain with which Zeus bound the two worlds, that of the immortals to that of the mortals. ${ }^{103}$ Crucially, the allegorical interpretation of the myth was developed by the Neoplatonists between the third and the fifth centuries CE, and Michael Psellos resumed these discussions in the middle of the eleventh century. ${ }^{104}$ Psellos traces the interpretations of the "golden chain «, first, to semi-mythical Orphic poetry; second, to Plato's Theaetetus and, thirdly to the Neoplatonic tradition. The relevant passage reads:

But these are their myth. Indeed, the creator, that Zeus, having fixed the first and second orders of the gods, in a way appropriate to an accord of agreement, placed that golden chain; for it is a symbol of their entanglement and bond. So the first were kept together with the second, the third with the second, and the rest by continuity, and all were relying on the First Principle, which according to the Hellenes [i.e., pagans] is Zeus. But the related natures, which were connected with the first god, cannot apply any restraint on Zeus, but he can easily pull them all towards him. The worst can turn to the best, but the best cannot turn to the worst, until they keep their proper order. Thus the body [can turn] to the soul, the soul towards the intellect, and the intellect can ascend towards god, but they cannot turn towards those that are subject to them. ${ }^{105}$

Psellos may name Iamblichus and Proclus in his treatise and include a digression to explain the views of Porphyry, but his interpretation of the mythical golden chain is ultimately rooted in Plotinus' Enneads (which were indeed recorded by Porphyry). ${ }^{106}$ Specifically, what lies behind Psellos' interpretation is the distinction between the intelligible world and the intellect, and what is even more important is the interest in the distinction between the sensible and intelligible world, and in the ascent of the intellect, which can subsequently lead to the One (which is the absolutely beautiful and good). ${ }^{107}$ The ascent to the level of the intellect is the ultimate aim for humanity according to the Ennead On Intellect, Ideas and Being (5.9). ${ }^{108}$

102 Roilos, Amphoteroglossia, 175-183. A connection with Neoplatonism is also found in the novel's very title, Roilos, Amphoteroglossia, 170-175.

103 Iliad 8.18-27; cf. Iliad, 15.14-33, trans. Lattimore, Iliad, pp. 200-201 and 330-331 respectively.

104 Michael Psellos, On the Golden Chain, no. 46, ed. Duffy, 164-168. There is no English translation available. For a translation in French see Lévêque, Aurea Catena Homeri, 78-81. The commentary on the Iliad by Eustathios of Thessaloniki, Commentary on the Iliad, ed. Van der Valk, 514, also includes an exegesis on the golden chain; Eustathius, however, mainly considers the stoic interpretation that the golden chain stands for the four elements. On Psellos in general, see Jenkins, Psellos.

105 The translation is ours. Michael Psellos, On the Golden Chain, no. 166, ed. Duffy, 52-64.

106 Regarding the references to Proclus, see Roilos, Amphoteroglossia, 176-177.

107 Plotinus, Ennead on Eros, 3.5.9, trans. Gerson et al., 302-303.

108 That would not be the first time that Psellos engages with Ennead 5.9; see Lauritzen, Psellos and Plotinos, 717-719. 
In a letter, Psellos proclaims his inclusion among this most elevated kind of human, pronouncing proudly: "As I profess philosophy [...] I should be attached only to the rgolden chain of heaven. ${ }^{109}$ What is also important for this discussion is that the higher human being aims to reside in a specific place, which for Psellos - who takes a lead from Plotinus' "well-governed fatherland " - becomes Heaven. If the Christian Heaven is associated with the ultimate garden, Eden/Paradise (paradeisos literally meaning "garden « ${ }^{100}$ ), Plotinus quite conveniently for the Christian discourse - locates this place in a garden:

It is in the Soul, then, that this expressed principle takes its place as it comes from Intellect, flowing into his [i.e., Zeus'] garden at the time when Aphrodite is said to be born.

And every garden is a glorious display and ornamental expression of wealth, but the domains of Zeus are brilliant with reason and his ornaments are the glories that enter into the Soul from Intellect itself. What could the garden of Zeus really be except the glorious image of his person? And what could his glories and adornments be other than the expressed principles which flow from him? The expressed principles taken together are identical with Plenty, his abundance and wealth of beautiful things already revealed. ${ }^{111}$

According to Plato, the garden of Zeus is where Eros was conceived. ${ }^{112}$ For Plotinus, the perfection of the garden of Zeus - often considered the same as the One - mirrors the virtuous nature of its maker. The reference here to a garden associated with the very existence of Eros is crucial for understanding pleasure. Pleasure for Neoplatonists derives from the desire to observe the One. ${ }^{113}$ That desire is driven by Eros and is addressed towards beauty and goodness. ${ }^{114}$ The highest pleasure is achieved by transcending to the level of the intellect and being unified, thanks to Eros, with the One. ${ }^{115}$

Returning to Hysmine and Hysminias, this Neoplatonic pleasure is the one Makrembolites endows his protagonist with, and which he invites the reader to observe. Makrembolites was acquainted with the rhetorical aesthetics preached by Psellos, ${ }^{116}$ but the passage from the novel quoted above takes the discourse a step further. The connection between the medieval novel and the ancient Ennead On Eros becomes established directly with Eros' image as an enthroned king ("Eros the King") depicted together with that of the cardinal virtues on the

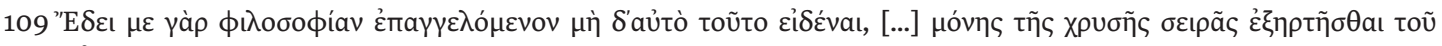
oủpavoũ. Papaioannou, Rhetoric and Authorship, 207-208.

110 Discussed in detail by Della Dora, Landscape, 93-117.

111 Ennead 3.5: On Eros, trans. Boys-Stones et al.

112 According to Diotima, Eros was conceived at a birthday party for Aphrodite, which took place in the garden of Zeus. Symposium, 203b, ed. Burnet, trans. Nehamas and Woodruff, Plato Symposium, 48.

113 Plotinus, Enneads, ed. Henry and Scwyzer, 1.1.5. Cf. Van Riel, Pleasure, 100. Neoplatonists like Plotinus place little importance on pleasure. In fact, the excerpt from Ennead 5.9 (On Intellect, Ideas and Being) is preceded by a declaration of the superiority of (Neo)Platonism in two schools of philosophy that had placed pleasure at the center of the discussion: Epicureans and Stoics. For Neoplatonism (as for Plato) pleasure is a pathêma. Maximos the Confessor, Ambigua (=On Difficulties) to John, Amb. 10.2b, ed. Constas, 16o, transl. 161.

114 Plotinus, Enneads, ed. Henry and Scwyzer, 5.9. Cf. Michael Psellos, Ekphrasis of Eros Carved on Stone, ed. Littlewood, no. 34, 11. 16-30, trans. Angelidi, 288-289.

115 Van Riel, Pleasure, 107-117.

116 Papaioannou, Michael Psellos, 248. 
wall surrounding Sosthenes' garden. ${ }^{117}$ The virtues are related to the ethical connotation of the garden in a Christian context, and, indeed, Psellos interprets the Neoplatonic discourse related to the golden chain as an allegory for Christian virtue: the One is the Christian God (a unity with three hypostaseis). God separated the sensible and the intelligible worlds, where humans and angels live. Humans can become angels, but angels cannot become humans. ${ }^{118}$ Reading the passage thus, the garden of Sosthenes retains pleasure because it functions as a place of transmutation between the Christian worlds. ${ }^{119}$

Virtues are important for pleasure in the classicizing garden of Eros the King. On the second day of their sojourn in Sosthenes' palace, Hysminias and his companion Kratisthenes once again praise the pleasure they receive in the garden in the most emphatic way possible:

On the following day, we went into the garden again, and fed our eyes with its charms (charis), drawing the pleasure (hédonē) down into our souls. For the garden was the abode of all good things, a dwelling place for the gods, and was all charm (charis) and pleasure (hédonē), a delight (terpsis) to the eyes, comfort to the heart, consolation to the soul, repose for the limbs and rest for the body. ${ }^{120}$

Pleasure, while not originally the central topic of Hysmine and Hysminias, comes to the center of the discussion. It is the beauty of the garden that causes this change of focus. Beauty and goodness are intimately related in post-fifth-century Greek philosophy and, according to Plotinus, beauty exists in virtue (aretē). As such, it can cause "pleasurable excitement" (ptoésin meth' hédonès). ${ }^{121}$ Thus, it is not surprising that in Makrembolites' description pleasure derives from all the "good things " in the garden, namely the classicizing depictions of the four cardinal virtues, Prudence, Fortitude, Chastity and Justice, as well as of Eros. ${ }^{122}$ The Neoplatonic idea that (good) pleasure co-exists with virtue (aretē) was developed further by a Neoplatonist par excellence of the twelfth century: Eustratios, the metropolitan of Nicaea. ${ }^{123}$ In his refutation against Islam, included in his commentary on Aristotle's Nicomachean Eth$i c s$, Eustratios suggests that the only good life is the one that contains pleasure led by virtue. ${ }^{124}$

117 Hysmine and Hysminias, II.2.1-11; IV.21. The connection with the garden of Zeus mentioned in the speech of Diotima in the Symposium becomes explicit in Hysmine and Hysminias, II.7. For a discussion of Eros in general in twelfth-century novelistic literature, see James, Eros, 410-411; Magdalino, Eros the king; Cupane, Eros basileus. For a different approach that suggests Makrembolites' direct or indirect dependence on Proclus, see Roilos, $\mathrm{Am}$ photeroglossia, 179-183.

118 Michael Psellos, On the Golden Chain, no. 46, ed. Duffy, 100-110.

119 On Christian allusions in Komnenian novels, see Burton, Reviving.

120 Hysmine and Hysminias, II.1.1. The passage is also translated and discussed in Walker, Domestic gardens.

121 Plotinus, Enneads, ed. Henry and Scwyzer, 1.4, especially lines, 15-17.

122 Hysmine and Hysminias, II.1-6. On the strategies of seeing the virtues, see Chatterjee, Viewing and description.

123 See, e.g., Trizio, Neoplatonismo. Eustratios, like Psellos, believed in the chain to which »the second term is always connected first and maintains similarity with it."Commentary in Nicomachean Ethics VI, 317, 30-32. For a detailed discussion, see Trizio, Eleventh- to twelfth-century Byzantium, 193.

124 On the Neoplatonic material of the commentary, see Trizio, Neoplatonic source-material; on the refutation of Islam, see Trizio, Neoplatonic refutation, with further parallel from Eustathios' commentary on the first book of the Aristotelian work. 
Neoplatonism was a form of classicizing learning, as it included studying texts from a vaguely defined yet revered past. In contrast to the classical texts included in the school curriculum, Neoplatonic interests were challenged throughout the late eleventh and twelfth centuries - given that Neoplatonism was seen as a threat against Orthodox Christianity. In 1082, Psellos' student and Eustatrios' teacher, Michael Italos, was condemned by the Church for his Neoplatonic beliefs. A few years later, Eustratios himself was tried for heresy. Nonetheless, Psellos, Eustratios, and Makrembolites were all connected to the higher aristocratic and administrative strata of the imperial capital. Psellos was the official consul of the philosophers and educator of an emperor, Michael VII Doukas (r. 1071-1078). Eustratios, a court theologian, composed his (Neoplatonic) commentary on the Nicomachean Ethics at the request of Anna Komnene, the aunt of Emperor Manuel I Komnenos (r. 1143-1180). ${ }^{125}$ Finally, Makrembolites' novel, like its contemporary counterparts, was written to entertain an aristocratic audience. ${ }^{126}$ And, indeed, a number of contemporary figures had an uneasy relationship with the revival of Neoplatonism essentially initiated by Psellos. ${ }^{127}$ That fear of persecution explains why Makrembolites had hidden references to Neoplatonic influences that could pass unnoticed by the average reader, while the pepaideumenoi would take double pleasure from the philosophy and the beautiful words of the descriptions.

For literati, pleasure in the garden derived from the beauty of colors and aromas, and from the excitements of (classicizing) learning similar to that discussed above. ${ }^{128}$ For instance, Constantine Manasses (c.1130-c.1187) admires the library in the church of Hagia Sophia, describing it as a garden with "book-bearing trees «. ${ }^{129}$ In an ekphrasis dating from the very beginning of the thirteenth century, fervent discussions of medicine are said to be conducted in the garden of the church of the Holy Apostles in Constantinople. ${ }^{130}$

An unpublished address by the intellectual Gregory Antiochos (?1125-after 1196) to his contemporary, the major patron of arts George Kamateros, exemplifies the delights of learning Antiochos was hoping to enjoy in the garden. Antiochos complains about the great preoccupations deriving from his post as a judge by recollecting good times past, when he was dedicated to studying and learning, as if he were living in "a sweet small garden" (glykyn képion). ${ }^{131}$ The wording "sweet small garden " indicates a protected and comfortable place. Such a place, we read next, would allow Antiochos to withdraw from his daily toils and labors in the imperial bureaucracy, and offer security. Antiochos describes his transition from a student of (classicizing) learning to an imperial official in terms of a new expulsion from

125 Trizio, Neoplatonismo, 22-74.

126 Trizio, Eleventh- to twelfth-century Byzantium, 200-201 and 203. See also Mariev, Neoplatonic Philosophy, 12-13. 127 See Trizio, Eleventh- to twelfth-century Byzantium, and Mariev, Neoplatonic Philosophy, 7-13.

128 For Classical and Hellenistic associations between the garden and learning, see Della Dora, Landscape, 94. The sensual perception of the garden can be found, for example, in all eleventh- and twelfth-century descriptions of gardens discussed in this article.

129 Constantine Manasses, Short Chronicle, ed. Lampsides, 4190-4197.

130 Nicholaos Mesarites (c.1163/1164-after 1216), Description, XLII, ed. Downey, trans. Angold, 129-130.

131 Logos to Andronikos Doukas Kamateros, Scor. Y.II.10, f. 380v-381. See Kazhdan and Franklin, Gregory, esp. $201-202$.

medieval worlds $•$ No. $13 \cdot 2021 \cdot 229-265$ 
Paradise (the Greek paradeisos also meaning "garden «). Our author fears that were he to have stayed in the garden, apolausis would have taken over the place of terpnotes (= noun from terpnos, a positive form of pleasure) and his eternal salvation would have been lost. Thus, Antiochos finds pleasure in the garden, but fears the consequences of that pleasure being experienced without pain and moderation.

If the personified virtues (together with the depiction of Eros) are said to fence off Sosthenes' garden in Hysmine and Hysminias, self-moderation of one's own pleasure in the garden is required by Theodore Prodromos in his poem On the Garden. ${ }^{132}$ Its exact date and context remain unknown, just as it remains unclear whether it was intended as a school exercise or a verse inscription. Yet, this poem of forty-four verses emphasizes a Christian understanding of the garden, which finds parallels to Neoplatonic worldviews evoking a restrained pleasure that could lead to the One. ${ }^{133}$

At first glance, the poem reads like a rhetorical exercise, with Prodromos advocating restrained enjoyment of the ample pleasures offered in the garden. »Here, a white lily!« Prodromos points out to the reader in the first stanza, but then immediately calls for caution: "Reap, but with chastity!« (v. 3). The second stanza is a memento mori, for Prodromos uses the blooming fields that wither in winter, as a figuration for the mortality of humanity. As Prodromos advocates, if humans think about death, Christians would think about Paradise and the joys offered in the divine garden. The text subsequently passes from the material world to the intelligibility of Eden in the third and fourth stanzas. The poet reflects again on the material garden. He addresses a personification of the garden with admiration for "how many pleasures [...] are teeming " and the delight he offers to the beholders in stanza four. In the last stanza, Prodromos speaks directly to the beholder: "the mortal " is asked to enjoy pleasure in the garden but to not forget that "nothing in life is free from toil and trouble." Prodromos starts from the earthly garden yet transitions to the divine. That full transition from the sensible garden to the intelligible one, Paradise, can only be achieved by an individual who chooses to practice true virtue. This includes self-restraint in this material world. ${ }^{134}$ Unmitigated choice is the kind of freedom one experiences in the earthly garden. If the choice is virtuous, then one can arrive at true self-realization: the return to the first condition of humanity and the return to the lost garden, Paradise.

132 New edition and translation, Theodore Prodromos, On a Garden, ed. Zagklas, 395-400. Cf. Nilsson, Nature controlled by artistry, 21-23.

133 On Prodromos and his relation to Neoplatonic circles, see Trizio, Neoplatonismo, 67-70, and Magdalino, Manuel, 390-391.

134 Cf. the discussion of virtues in Plotinus, Enneads, ed. Henry and Scwyzer, 1.2: On Virtues, according to which, practicing a virtuous stance is related to the sensible world. 


\section{Conclusions}

Our comparative examination of the discourses of pleasure in Byzantium and China during the eleventh and twelfth centuries reveals two rather different political, cultural and conceptual worlds. Among many significant contrasts, several have been highlighted here. While Byzantine literati mostly wrote about gardens that they did not own, and in a genre that was rhetorically designed to evoke pleasure, Chinese literati often wrote about gardens that they owned, and in an autobiographical mode that was also a literary self-performance before a wider literati public. While Byzantine gardens were primarily walled urban gardens, and their literary depictions emphasized that they were places of security and protection, the private gardens that Chinese literati wrote about tended to emphasize open vistas afforded by pavilions and elevated outlooks.

A further contrast involves approaches to the body. In narratives of Chinese gardens, the body assumes considerable significance, with bodily experience becoming the very site of meaningful engagement with the garden. References to the body in Byzantine sources are limited when compared to sources from the Song era. When they do appear - as in the case of Makrembolites' texts - they are related to senses rather than to the body itself. ${ }^{135}$ This difference reveals an essential divergence in the nature of the discourse of the garden between the two cultures. Byzantine authors were following the principles of mimesis (imitation) when writing about gardens. They were using literary examples from the past, often to describe what were imaginary worlds. The body as such was not included in this discourse. ${ }^{136}$ By contrast, Song literati emphasized their personal experience, and also drew from an ancient tradition in which the body was understood as the starting point of engagement with the world. ${ }^{137}$ It was thus not surprising that Song intellectuals seeking inspiration and validation from the ancients, and increasingly cognizant of the workings of the body, ${ }^{138}$ would emphasize bodily experience in their writings about self-cultivation and personal realization.

A final point of comparison is the very means of experiencing pleasure in relation to the garden. In the Song writings considered here, pleasure was defined not so much in terms of objects, as attributes of a virtuous character, and as part of a statement about the very meaning of true virtue and the properly realized life. Byzantine gardens, for their part, functioned as ethical places in which pleasure (in a form that was virtuous or not) could befall someone. At a first level, that pleasure came from a harmonious unity of beautiful elements in an essentially built environment. At a second level, given that these were places that were to be experienced through literature, the true pleasure available to the audience was a statement of the writer's skills.

135 See above, 250.

136 Although the body had acquired a special significance in the twelfth century; see, Kazhdan, Körper.

137 On the centrality of the body and its role as the most intimate layer of the spatial ordering of reality in early China, see Lewis, Construction of Space, 13-76.

138 Not coincidentally, it was during the Song period that we find an empire-wide, court-sponsored campaign that sought to systematize medical knowledge, resulting in major advancements in the visual and spatial understanding of the workings of the body as an integrated whole. See Goldschmidt, Evolution of Chinese Medicine. 
Despite these differences, however, there are some striking commonalities as well. Most basic is the conception of the garden as a space of ethical progress and self-realization. In Byzantium, this virtue is realized not so much by the act of shaping the garden (a privilege only for the few), as by the selective and thus personal viewing of a fenced area. ${ }^{139}$ As landscape becomes a spectacle that is witnessed through the gaze of an individual, it is the nature (physis) of the viewer that defines whether the beholder will receive virtuous pleasure or its opposite from the part of the natural environment (also termed as physis) included in the fenced area of a garden. For their Chinese literati counterparts, the garden was a place to be transformed physically into a meaningful landscape through which one could navigate and experience one's freedom of movement, choice and creativity. But regardless of whether one actually owned and worked the garden that one was writing about - with Chinese literati literally fashioning out of their gardens a topographical emblem of their ideal selves, performed before others, while their Byzantine counterparts built beautiful rhetorical structures - for both, the garden became a place through which an ideal self could be cultivated, realized, and ultimately, expressed.

Another important commonality in the literary construction of the garden as a potential place of virtue is the role of classicization - here pointing not necessarily to ancient canonical texts, or to the ancient Greek tradition, in the Byzantine case, but to an idealized past embodying what was held as timeless principles or values. In Byzantium, the garden's association with the Garden of Eden, the paradigmatic, mythical garden in the Christianized world, made it, by definition, an ethically charged space. As shown above, the ethical significance of the garden was heightened as a result of the prominence of Neoplatonism. In Song China, in the absence of a mythology of a specific original or ideal garden that would have such an enduring and powerful hold over the imagination of later thinkers, ${ }^{140}$ framing the garden as an ethically meaningful landscape was achieved through references to a constantly shifting repertoire of iconic past figures and texts.

Finally, in both the Chinese and Byzantine discourses, there was a deep relationship between pleasure and virtue. Pleasure was clearly conceived of as more than just a psychological or affective state: it was the evidence of a virtuous life, as achieved through the proper channels. True virtue entailed pleasure, and an important part of the literati interest in the garden was to furnish an arena in which the individual could achieve something like virtuous pleasure. The discourse of pleasure thus became part of an ethically complex package in which pleasure was vital to one's moral (and physical) well-being.

These commonalities ultimately point towards the world beyond Byzantium and China, potentially opening up space for further explorations in global approaches to the philosophy of pleasure, as well as to the cross-cultural history of gardens. Philosophically, the fascinating accounts of pleasure promulgated in these eleventh- and twelfth-century garden texts put into perspective the limits of certain modern approaches to pleasure in terms of pleasurable

139 A different aspect of the garden in fourteenth-century Byzantine romances as a place of female power and freedom emerges in the study of Kirsty Stewart, Literary landscapes (with further references).

140 Early poetic and mythological writings in China do contain accounts of gardens as fantastic, paradise-like places, the earliest known instances being in several poems included in the famous second century CE anthology, The Songs of Chu (Chu ci 楚辭), attributed to Qu Yuan 屈原 (c. 339-278 BCE), an official and poet from the state of Chu 楚. However, this text was not much invoked by the Song writers, who resorted rather to the canonical, classical writings, and to later historical figures deemed to embody the values they associated with the ancient sages. 
feelings, ${ }^{141}$ and suggest that the more complex approach that links pleasure with virtue might not have been an aberration but rather a norm in the premodern world. In terms of the history of gardens, this preliminary study of the diverging yet resonant discourses of pleasure in the garden in Byzantium and China could be the starting point for further conversations among scholars working in other classicizing traditions about how pleasure, Antiquity and virtue might have come together in the ethical space of the garden.

\section{Acknowledgements}
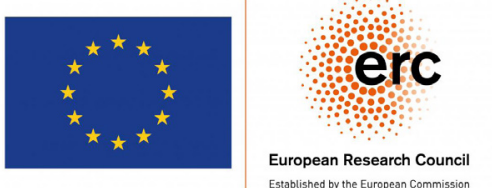

European Research Council

This article was completed as part of the project PAIXUE. Classicising Learning in Medieval Imperial Systems: Cross-cultural Approaches to Byzantine Paideia and Tang/ Song Xue, which has received funding from the European Research Council (ERC) under the European Union's Horizon 2020 research and innovation program (grant agreement no. 726371, 2017-2022).

We would like to thank the anonymous reviewers of this paper for their valuable comments and suggestions.

141 For recent critical discussions of this hedonistic approach, see, Nico Frijda, Nature of pleasure; and Duncker, Pleasure, emotion and striving. For a recent study that highlights the diversity and complexity of approaches to pleasure in the history of philosophy, see Shapiro, Pleasure. A History. 


\section{References}

Achilles Tatius, Leukippe and Kleitophon, ed. Ebbe Vilborg, Leucippe and Clitophon, 2 vols. (Stockholm, 1955-1962). English translation: John J. Winkler, in: Brian P. Reardon (ed.), Collected Ancient Greek Novels (Berkeley, CA, 2008) 175-284.

Barber, Charles, Reading the garden in Byzantium: Nature and sexuality, Byzantine and Modern Greek Studies 16/1 (1992) 1-20.

Barber, Charles and Stratis Papaioannou, Michael Psellos on Literature and Art: A Perspective on Aesthetics (Notre Dame, IN, 2017).

Bol, Peter K., Government, society, and state: On the political visions of Ssu-ma Kuang and Wang An-shih, in: Robert P. Humes and Conrad Schirokauer (eds.), Ordering the World: Approaches to State and Society in Sung Dynasty China (Berkeley, 1993) 128-192.

Bol, Peter K., Neo-Confucianism in History (Cambridge, MA, 2008).

Bol, Peter K., "This Culture of Ours«: Intellectual Transitions in T'ang and Sung China (Stanford, 1992).

Booth, Phil, Maximos the Confessor in: Anthony Kaldellis and Niketas Siniossoglou (eds.), The Cambridge Intellectual History of Byzantium (Cambridge, 2018) 414-430.

Burton, Joan B., Reviving the pagan Greek novel in a Christian world, Greek, Roman and Byzantine Studies 39 (1998) 179-216.

Bynum, Caroline, Did the twelfth century discover the individual?, The Journal of Ecclesiastic History 31/1 (1980) 1-17.

Campbell, Duncan, and Alison Hardie. The Dumbarton Oaks Anthology of Chinese Garden Literature. Ex Horto: Dumbarton Oaks Texts in Garden and Landscape Studies (Washington, D.C., 2020).

Chaffee, John W., Introduction: Reflections on the Sung, in: John W. Chaffee and Denis Twitchett (eds.), The Cambridge History of China. 5/2: Sung China, 960-1279 AD (Cambridge, 2015) 1-18.

Chaffee, John W., Sung Education: Schools, Academies, and Examinations, in: John W. Chaffee and Denis Twitchett (eds.), The Cambridge History of China. 5/2: Sung China, 96o1279 AD (Cambridge, 2015) 286-320.

Chatterjee, Paroma, Viewing and description in "Hysmine and Hysminias «: The fresco of the virtues, Dumbarton Oaks Papers 67 (2013) 209-225.

Clunas, Craig, Fruitful Sites: Garden Culture in Ming Dynasty China, Envisioning Asia, Reaktion Books (London, 1996).

Confucius, 論語, Lunyu [Analects], ed. Din-cheuk (D.C.) Lau, Ho Che Wah and Chen Fong Ching, 論語逐字索引, Lunyu zhu zi suo yin [A Concordance to the Lunyu], ICS Series (Hong Kong, 1995). English translation: Edward Slingerland, Confucius: Analects. With Selections from Traditional Commentaries (Indianapolis, 2003).

Constantine Manasses, Short Chronicle, ed. Odysseas Lampsides, Constantini Manassis Breviarium, Chronicum, Corpus Fontium Historiae Byzantinae 36/1 (Athens, 1996).

Constantinides, Costas N., Byzantine gardens and horticulture in the late Byzantine period, 1204-1453: The secular sources, in: Antony Littlewood, Henry Maguire and Joachim Wolschke-Bulmahn (eds.), Byzantine Garden Culture (Washington, D.C., 2002) 87-103.

Constas, Maximos, On difficulties in the Church Fathers. The Ambigua. Maximos the Confessor, Dumbarton Oaks Medieval Library 1 (Washington, D.C., 2014). 
Constas, Maximos, Maximus the Confessor, Dionysius the Areopagite, the Transformation of Christian Neoplatonism, Analogia 1/2 (2017) 1-12.

Cupane, Carolina, Eros basileus: La figura di Eros nel romanzo bizantino d'amore, Atti del'Academia di Scienze Lettere e Arte di Palermo 4.33/2 (1974) 197-204.

Curtius, Ernst Robert, Europäische Literatur und lateinisches Mittelalter (Bern, 1948).

Demoen, Kristoffel, Classicizing elements in John Geometres' Letters about his garden, in: Proceeding of the Eleventh International Congress of Classical Studies Kavala, Greece 1999, 1 (Athens, 2001) 215-230.

Demoen, Kristoffel, A Homeric garden in tenth-century Constantinople: John Geometres' rhetorical Ekphraseis of his estate, in: Helena Bodin and Ragnar Hedlund (eds.), Byzantine Gardens and Beyond (Uppsala, 2013) 114-127.

Destrée, Pierre, Pleasure, in: Pierre Destrée and Penelope Murray (eds.), A Companion to Ancient Aesthetics, Blackwell Companions to the Ancient World (Malden, MA, 2015) 472-485.

Della Dora, Veronica, Landscape, Nature, and the Sacred in Byzantium (Cambridge, 2016).

Digenis Akrites, ed. and trans. Elizabeth Jeffreys, Digenis Akritis: The Grottaferrata and Escorial Versions (Cambridge, 1998).

Duncker, Karl, On pleasure, emotion, and striving, Philosophy and Phenomenological Research 1/4 (1941) 391-430.

Egan, Ronald. The Problem of Beauty: Aesthetic Thought and Pursuits in Northern Song Dynasty China (Cambridge, MA, 2006). Accessed on 19 April 2021: doi:10.2307/j.ctt1tm7frm.

Elsner, Jaś, Introduction: The genres of Ekphrasis, Ramus 31/1-2 (2002) 1-18.

Eustathios Makrembolites, Hysmine and Hysminias, ed. Miroslav Marcovich, Eustathius Macrembolites: De Hysmines et Hysminiae amoribus libri XI (Munich, 2001). English translation: Elizabeth Jeffreys, Four Byzantine Novels, Translated Texts for Byzantinists 1 (Liverpool, 2012) 176-279.

Eustathios of Thessaloniki, Commentary on the Iliad, ed. Marchinus Van der Valk, Eustathii archiepiscopi Thessalonicensis commentarii ad Homeri Iliadem pertinentes 2 (Leiden, 1976).

Fowler, Ryan, The Second Sophistic, in: Lloyd P. Gerson (ed.), The Cambridge History of Philosophy in Late Antiquity (Cambridge, 2000) 100-114.

Frijda, Nico, The nature of pleasure, in: John A. Bargh and Deborah K. Apsley (eds.), Unraveling the Complexities of Social Life: A Festschrift in Honor of Robert B. Zajonc (Washington, 2002) 71-94.

Fuller, Michael A., The Road to East Slope: The Development of Su Shi's Poetic Voice (Stanford, 1990).

Gaul, Niels, The manuscript tradition, in: Egbert J. Bakker (ed.), Companion to the Ancient Greek Language (Oxford, 2010) 69-81.

Gibson, Craig, A., Libanius' Progymnasmata: Model Exercises in Greek Prose Composition and Rhetoric (Atlanta, 2008.)

Goldschmidt, Asaf, The Evolution of Chinese Medicine: Song Dynasty, 960-120o (New York, 2009). 
Gregory Antiochos, Letter to the Bishop of Kastoria, ed. Eugenia Drakopoulou and Marina Loukaki, E Anakdote epistole tou Gregoriou Antiochou pros ton episkopo Kastori-

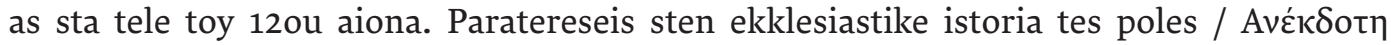

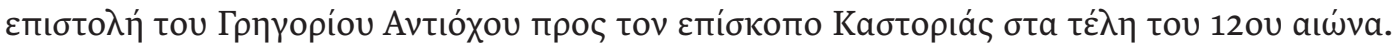

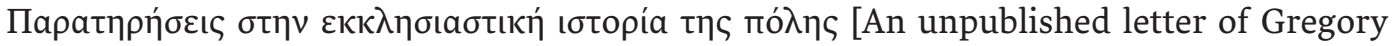
Antiochos to the bishop of Kastoria at the end of the 12th century. Observations on the city's church history], Byzantiaka 9 (1989) 121-137.

Guo Xi 郭熙, 林泉高致集, Linquan gaozhiji [The Lofty Message of Forests and Streams Collection], Siku Quanshu (electronic edition).

Harbsmeier, Christoph, The semantics of Qing in pre-Buddhist Chinese, in: Halvor Eifring (ed.), Love and Emotions in Traditional Chinese Literature (Leiden, 2004).

Hargett, James, Huizong's magic marchmount: The Genyue pleasure park of Kaifeng, Monumenta Serica 38 (1988-1989) 1-48.

Harrist, Robert E., Jr., Site names and their meaning in the Garden of Solitary Enjoyment, Journal of Garden History 13/4 (1993) 199-212.

Harrist, Robert E., Jr., Art and identity in the northern Sung dynasty: Evidence from gardens, in: Maxwell K. Hearn and Judith G. Smith (eds.), Arts of the Sung and Yüan (New York, 1996) 147-163.

Harrist, Robert E., Jr. and Gonglin Li, Painting and Private Life in Eleventh-Century China: Mountain Villa by Li Gonglin (Princeton, 1998).

Hartman, Charles, Sung government and politics, in: John W. Chaffee and Denis Twitchett (eds.), The Cambridge History of China. 5/2: Sung China, 960-1279 AD (Cambridge, 2015) 19-138.

Hass, Petra, Der locus amoenus in der antiken Literatur: $Z u$ Theorie und Geschichte eines literarischen Motivs (Bamberg, 1998).

Heath, Malcolm, Unity, wholeness, and proportion, in: Pierre Destrée and Penelope Murray (eds.), A Companion to Ancient Aesthetics, Blackwell Companions to the Ancient World (Malden, MA, 2015) 380-392.

Henderson, John. Hortus: The Roman Book of Gardening (London, 2004).

Hinterberger, Martin, Emotions in Byzantium, in: Liz James (ed.), A Companion to Byzantium (Oxford, 2010) 123-134.

James, Liz, Eros, literature and the Veroli casket, in: Teresa Shawcross and Ida Toth (eds.), Reading in the Byzantine Empire and Beyond (Cambridge, 2018) 397-413.

Jeffreys, Elizabeth, Four Byzantine Novels, Translated Texts for Byzantinists 1 (Liverpool, 2012).

Jenkins, David, Michael Psellos, in: Anthony Kaldellis and Niketas Siniossoglou (eds.), The Cambridge Intellectual History of Byzantium (Cambridge, 2018) 447-461.

Kaldellis, Anthony, Classical scholarship in twelfth-century Byzantium, in: Charles Barber and David Jenkins (eds.), Medieval Greek Commentaries on the Nicomachean Ethics (Leiden, 2009) 1-43.

Kazhdan, Alexander, Der Körper im Geschichtswerk des Niketas Choniates, in: Günter Prinzing and Dieter Simon (eds.), Fest und Alltag in Byzanz (Munich, 1990) 91-102.

Kazhdan, Alexander and Benjamin Franklin, Gregory Antiochus: writer and bureaucrat, in: Alexander Kazhdan and Benjamin Franklin, Studies on Byzantine Literature of the Eleventh and Twelfth Centuries (Cambridge, 1984) 196-223.

Kazhdan, Alexander and Ann Wharton Epstein, Change in Byzantine Culture in the Eleventh and Twelfth Centuries (Berkeley, 1985). 
Kern, Martin, Ritual, text, and the formation of the canon: Historical transitions of »Wen« in early China, T'oung Pao, Second Series 87/1 (2001) 43-91.

Laozi, Laozi Dadodejing 老子道德經: Sibu Congkan 四部叢刊 (Shanghai, 1929).

Lattimore, Richmond, The Iliad of Homer (second edition), (Chicago, 2011).

Lauritzen, Frederick, Psellos and Plotinos, Byzantinische Zeitschrift 107/2 (2014) 711-724.

Lauxtermann, Marc D., Byzantine Poetry from Pisides to Geometres: Texts and Context 2 (Vienna, 2019).

Lévêque, Pierre, Aurea Catena Homeri: Une étude sur l'allégorie grecque (Paris, 1958).

Lewis, Mark E., The Construction of Space in Early China (Albany, 2005).

Libanios, Ekphrasis of a Garden: Progymnasmata, ed. Richard Foerster, Libanii opera, 8 vols. (Leipzig, 1915). English translation: Craig A. Gibson, Libanius's Progymnasmata: Model Exercises in Greek Prose Composition and Rhetoric 9 (Atlanta, 2008) 447-449.

Li Gefei 李格非, 洛陽名園記, Luoyang ming yuan ji, Siku Quanshu (electronic edition).

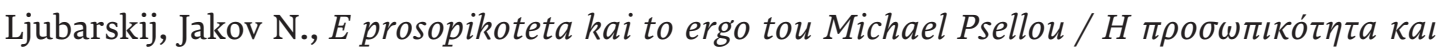

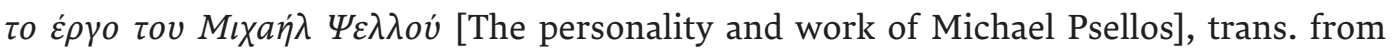
Russian by Argyro Tselepi (second revised edition), (Athens, 2004).

Lin, Shuen-fu, A good place need not be a nowhere: The garden and utopian thought in the Six Dynasties, in: Cai Zongqi (ed.), Chinese Aesthetics: The Ordering of Literature, the Arts, and the Universe in the Six Dynasties (Honolulu, 2004) 123-166.

Littlewood, Antony R., Romantic paradises: The rôle of the garden in the Byzantine romance, Byzantine and Modern Greek Studies 5/1 (1970) 95-114.

Littlewood, Antony R., The Progymnasmata of Ioannes Geometres (Amsterdam, 1972).

Littlewood, Antony, R., Gardens of the Byzantine world, in: Helena Bodin and Ragnar Hedlund (eds), Byzantine Gardens and Beyond, Studia Byzantine Upsaliensia (Upsalla, 2013) 30-113.

Liu, James T. C., An early Sung reformer: Fan Chung-yen, in: John K. Fairbank (ed.), Chinese Thought and Institutions (Chicago, 1957).

Magdalino, Paul, Eros the king and the King of »Amours": Some observations on »Hysmine and Hysminias", Dumbarton Oaks Papers 46 (1992) 197-204.

Magdalino, Paul, The Empire of Manuel I Komnenos (Cambridge, 1993).

Maguire, Henry, Paradise withdrawn, in: Antony Littlewood, Henry Maguire and Joachim Wolschke-Bulmahn (eds.), Byzantine Garden Culture (Washington, D.C., 2002) 23-35.

Maguire, Henry, Nectar \& Illusion. Nature in Byzantine Art and Literature (Oxford, 2012).

Makeham, John, The Confucian role of names in traditional Chinese gardens, Studies in the History of Gardens and Designed Landscapes 18/31 (1998) 187-210.

Mariev, Sergei, Neoplatonic philosophy in Byzantium, in: Sergei Mariev (ed.), Byzantine Perspectives on Neoplatonim (Berlin, 2017) 1-30

Maximos the Confessor, Ambigua, ed. Maximos Constas, On difficulties in the Church Fathers. The Ambigua. Maximos the Confessor, Dumbarton Oaks Medieval Library 1 (Washington, D.C., 2014).

McGrath, Michael, The reigns of Jen-tsung (1022-1063) and Ying-tsung (1063-1067), in: Denis Twitchett and Paul Jakov Smith (eds.), The Cambridge History of China. 5/1: Sung China, 960-1279 AD (Cambridge, 2009) 279-346.

Mencius, 孟子 Mengzi, ed. Din-cheuk (D.C.) Lau, Ho Che Wah and Chen Fong Ching, 孟子 逐字索引, Mengzi zhu zi suo yin [A Concordance to the Mengzi], ICS Series (Hong Kong, 1995). 
Mencius, Mengzi: With Selections from Traditional Commentaries, trans. from classical Chinese by Brian W. Van Norden (Indianapolis, 2008).

Michael Psellos, Chronographia, ed. Salvatore Impellizzeri, Michele Psello: Imperatori di Bisanzio (cronografia), 2 vols. (Milan, 1984). English translation: Edgar Robert Ashton Sewter, The Chronographia of Michael Psellos (London, 1959).

Michael Psellos, Ekphrasis of Eros Carved on Stone, ed. Antony Littlewood, Michaelis Pselli oratoria minora (Leipzig, 1985) no. 34, 1l. 16-30. English translation: Christine Angelidi, in: Charles Barber and Stratis Papaioannou (eds.), Michael Psellos on Literature and Art: A Perspective on Aesthetics (Notre Dame, IN, 2017) 288-289.

Michael Psellos, Ekphrasis or Allegory of Circe, ed. Antony Littlewood, Michaelis Pselli oratoria minora (Leipzig, 1985) no. 33, 1l. 18-22. Translation Christine Angelidi, in: Charles Barber and Stratis Papaioannou (eds.), Michael Psellos on Literature and Art: A Perspective on Aesthetics (Notre Dame, IN, 2017) 287-288.

Michael Psellos, On the Golden Chain, ed. John M. Duffy, Michaelis Pselli Philosophica Minora 1, no. 46 (Stuttgart, 1992) 164-168.

Myers K. Sara, Docta Otia: Garden Ownership and Configurations of Leisure in Statius and Pliny the Younger, Arethusa 38 (2005) 103-129.

Nemesios, On the Nature of Man, ed. Moreno Morani, Nemesius: De natura hominis (Leipzig, 1987). English translation:R. W. Sharples and Philip J. Van der Eijk, Nemesius: On the Nature of Man, Translated Texts for Historians 49 (Liverpool, 2008).

Nicholas Mesarites, Description of the Church of the Holy Apostles, ed. George Downey, Nikolaos Mesarites: Description of the Church of the Holy Apostles at Constantinople, Transactions of the American Philosophical Society, new series 47 (1957) 897-918. English translation: Michael Angold, Nicholas Mesarites: His Life and Works, Translated Texts for Byzantinists (Liverpool, 2107) 75-133.

Niketas Eugenianos, Drossila and Charikles, ed. Fabrizio Conca, I romanzo bizantino del XII (Turin, 1994) 305-497. English translation: Elizabeth Jeffreys, Four Byzantine Novels (Liverpool, 2012) 305-497.

Nilsson, Ingela, Erotic Pathos, Rhetorical Pleasure: Narrative Technique and Mimesis in Eumathios Makrembolites' Hysmine and Hysminias (Uppsala, 2001).

Nilsson, Ingela, Static imitation or creative transformation? Achilles Tatius in Hysmine and Hysminias, in: Stelios Panayotakis, Maaike Zimmerman and Wytse Keulen (eds.), The Ancient Novel and Beyond, Mnemosyne Supplementum 241 (Leiden, 2003) 371-380.

Nilsson, Ingela, Nature controlled by artistry: The poetics of the literary garden in Byzantium, in: Helena Bodin and Ragnar Hedlund (eds.), Byzantine Gardens and Beyond (Uppsala, 2013) 15-29.

Nilsson, Ingela, Raconter Byzance: La littérature au XIIe siècle, Séminaires Byzantins (Paris, 2014).

Nilsson, Ingela, Romantic love in rhetorical guise: The Byzantine revival of the twelfth century, in: Carolina Cupane and Bettina Krönung (eds.), Fictional Storytelling in the Medieval Eastern Mediterranean and Beyond (Leiden, 2016) 39-66.

Nilsson, Ingela, Ekphrasis, in: Foteini Spingou (ed.), The Visual Culture of Later Byzantium (c. 1081-c. 1350), Sources for Byzantine Art History 3 (Cambridge, 2021) 1249-1254.

Nilsson, Ingela and Nikos Zagklas, "Hurry up, reap every flower of the Logoi!«: The use of Greek novels in Byzantium, Greek, Roman, and Byzantine Studies 57 (2017) 1120-1148.

Nylan, Michael, The Chinese Pleasure Book (New York, 2018).

Ouyang Xiu, Ouyang Xiu Quanji 歐陽修全集, ed. Li Yi’an (Beijing, 2001). 
Owen, Stephen, The formation of the Tang estate poem, Harvard Journal of Asiatic Studies 55/1 (1995) 39-59.

Pagán, Victoria Emma, Rome and the Literature of Gardens (London, 2006).

Papaioannou, Stratis, Michael Psellos: Rhetoric and Authorship in Byzantium (Cambridge, 2013).

Plato, Symposium, ed. John Burnet, Platonis opera 2 (Oxford, 1901) St III.172a-223d. English translation: Alexander Nehamas and Paul Woodruff, Plato Symposium (Indianapolis, 1989).

Plotinus, Enneads, ed. Paul Henry and Hans-Rudolf Scwyzer, Enneads, Plotini Opera (Oxford, 1951-1973). English translation (and critical notes on the Greek text): Lloyd P. Gerson, George Boys-Stones, R. A. H. King, Andrew Smith and James Wilberding, Plotinus: The Enneads (Cambridge, 2017).

Roilos, Panagiotis, Amphoteroglossia. A poetics of the twelfth-century medieval Greek novel, Hellenic Studies 10 (Cambridge, MS, 2005).

Schönbeck, Gerhard, Der locus amoenus von Homer bis Horaz ([Heidelberg], 1962).

Shao Bowen, 邵伯温, 邵氏聞見錄, Shaoshi wenjian lu [Shao's Records of Things Seen and Heard] (Beijing, 1997).

Shao Yong, 邵雍, 擊壤集, Yichuan Jirang ji, ed. Okada Takeshi (Taipei, 1972).

Shao Yong, 邵雍, 皇極經世書, Huangji jingshi shu, ed. Wei Shaosheng and annot. Huang Ji (Zhengzhou Shi, 1993).

Sharples, Robert W. and Philip Van der Eijk, Nemesius: On the Nature of Man, Translated Texts for Historians 49 (Liverpool, 2008).

Sima Guang, 溫國文正司馬公文集, Wenguo wenzheng Sima Gong wenji [The Literary Collection of Sima Guang], Sibu Congkan 四部叢刊 (Shanghai, 1929).

Sima Guang, 獨樂園記, Du le yuan ji [Record of the Garden of Solitary Pleasure], in: The Craft of Gardens, trans. from classical Chinese by Alison Hardie (New York, 2012) 122-123.

Spingou, Foteini, Epigrams on works of art, in: Foteini Spingou (ed.), The Visual Culture of Later Byzantium (c. 1081-c. 1350). Sources for Byzantine Art History 3 (Cambridge, 2021) 1291-1297.

Spingou, Foteini, Introduction, in: Foteini Spingou (ed.), The Visual Culture of Later Byzantium (c. 1081-c. 1350). Sources for Byzantine Art History 3 (Cambridge, 2021) xliii-lxxvi.

Stewart, Kirsty, Literary landscapes in the Palaiologan romances: An ecocritical approach, in: Adam J. Goldwyn and Ingela Nilsson (eds.), Reading the Late Byzantine Romance: A Handbook (Cambridge, 2019) 272-298.

Su Shunqin, 蘇舜欽, Su Xueshi Wenji 蘇學士文集, Sibu Congkan 四部叢刊 (Shanghai, 1929).

Theodore Metochites, Poems, ed. Ioannis Polemis, Theodori Metochitae Carmina, Corpus Christianorum Series Graeca 83 (Turnhout, 2015). English translation: Ioannes Polemis, Theodore Metochites: Poems. Introduction, Translation, and Notes, Corpus Christianorum in Translation (Turnhout, 2016).

Theodore Prodromos, On a Garden, ed. and trans. Nikos Zagklas, Theodore Prodromos: The Neglected Poems and Epigrams (Edition, Translation and Commentary). Unpublished $\mathrm{PhD}$ thesis (University of Vienna, 2014).

Tian, Xiaofei, Collections, in: Wiebke Denecke, Wai-yee Li and Xiaofei Tian (eds.), The Oxford Handbook of Classical Chinese Literature (1000 BCE-9oo CE) (New York, 2017) 219-234.

Tinnefield, Franz Hermann, Kategorien der Kaiserkritik in der byzantinischen Historiographie von Prokop bis Niketas Choniates (Munich, 1971). 
Trizio, Michele, Neoplatonic source-material in Eustratios of Nicaea's commentary on Book VI of the Nicomachaen Ethics, in: Charles Barber and David Jenkins (eds.), Medieval Greek Commentaries on the Nicomahean Ethics (Leiden, 2009) 101-171.

Trizio, Michele, A neoplatonic refutation of Islam from the time of the Komnenoi, in: Andreas Speer and Philipp Steinkrüger (eds.), Knotenpunkt Byzanz: Wissensformen und kulturelle Wechselbeziehungen, Kölner Mediaevistentagung 14.-17. September 2010 (Berlin, 2012) 145-166.

Trizio, Michele, Eleventh- to twelfth-century Byzantium, in: Stephen Gersh (ed.), Interpreting Proclus: From Antiquity to the Renaissance (Cambridge, 2014) 182-225.

Trizio, Michele, In neoplatonismo di Eustazio di Nicea (Bari, 2016).

van Riel, Gerd, Pleasure and the Good Life: Plato, Aristotle, and the Neoplatonists, Philosophia Antiqua 85 (Leiden, 2000).

Virág, Curie, »That Which Encompasses the Myriad Cares«: Subjectivity, Knowledge, and the Ethics of Emotion in Tang and Song China. Unpublished PhD thesis (Harvard University, 2004).

Virág, Curie, Emotions and human agency in the thought of Zhu Xi, Journal of Song Yuan Studies 37 (2007) 49-88.

Virág Curie, Self-cultivation as Praxis in Song neo-Confucianism, in: John Lagerwey (ed.), Modern Chinese Religion: Value Systems in Transformation (Leiden, 2014) 1187-1232.

Virág, Curie, The Emotions in Early Chinese Philosophy (New York, 2017).

Ventresque, Renée, Le locus amoenus: Variations autour d'un paysage ideal, Cartes blanches 2 (Paris, 2002).

Walker, Alicia, Domestic garden sculpture and wallpainting in the romance Hysmine and Hysminias, in: Foteini Spingou (ed.), The Visual Culture of Later Byzantium (c. 1081-c. 1350). Sources for Byzantine Art History 3 (Cambridge, 2021) 307-342.

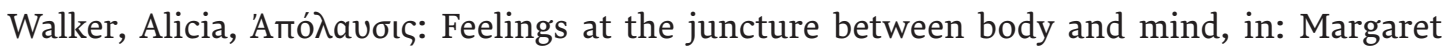
Mullett and Susan Harvey (eds.), Byzantine Emotions (Washington, D.C., forthcoming).

Watson, Philip, "Famous Gardens of Luoyang " by Li Gefei, Studies in the History of Gardens and Designed Landscapes 24/1 (2004) 38-54.

West, Stephen, Spectacle, ritual, and social relations: The Son of Heaven, citizens, and created space in imperial gardens in the Northern Song, in: Michael Conan (ed.), Baroque Garden Cultures: Emulation, Sublimation, Subversion (Washington D.C., 2005) 291-320.

West, Stephen, Zhu Changwen and his "Garden of Joy«, in: Mei-yi Lin (ed.), The Transmission and Interpretation of the Chinese Literary Canon: Papers from the Fourth International Conference on Sinology (Taipei, 2013) 203-253.

$\mathrm{Xu}$, Yinong, Interplay of image and fact: The Pavilion of Surging Waves, Suzhou, Studies in the History of Gardens \& Designed Landscapes 19/3-4 (1999) 288-301.

Yang, Xiaoshan, Metamorphosis of the Private Sphere: Gardens and Objects in Tang-Song Poetry (Cambridge, MA, 2003).

Yang, Xiaoshan, Li Gefei's "Luoyang Mingyuan Ji« (A record of the celebrated gardens of Luoyang): Text and context, Monumenta Serica 52 (2004) 221-255.

Zhuangzi 莊子, ed. Din-cheuk (D.C.) Lau, Ho Che Wah and Chen Fong Ching, 莊子逐字索引 [A Concordance to the Zhuangzi], ICS Series (Hong Kong, 2000). 